\title{
5 CASE TWO: Reversals of Negatiave Body-Law in the United States
}

\subsection{Introduction}

If the events in Indiana in 1907 and in Norway in 1934 represent one set of social norm inclusion into legal norms, can we find an antithetical set of events in order to compare them with Case One, in order to test my theories in that case? In other words can we find the "worst" and the "best" examples of body-law - or at least two very different examples - that the United States and Norway have to offer? Can we find a moment when the intersubjective categories in Case One changed configurations and/or gained in strength so that the "strong we" and the "weak we" occupied significantly different societal positions? Or, as Bourdieu might have asked, can we find a time when the "double naturalization" of bodies changed, when the "silent and invisible agreement between social structures and mental structures" changed so that the "law of the social body" was not converted into the "law of the physical body"? 686

In the United States, the legal discourse that was ultimately linked with the idea that, within the realm of married life, heterosexual couples could legally use birth control was the discourse of "privacy" articulated in the Supreme Court case of Griswold v. Connecticut, 381 U.S. 479 (1965). Griswold stood on a socio-legal foundation consisting of a number of failed legal cases as well as various political strategies by activists, and strategic framings that stretched back to the turn of the century. But after Griswold was decided, it would take only eight years before the right to reproductive privacy for married couples would develop into the right to an abortion for any woman, pregnant less than 12 weeks, as outlined in Roe v. Wade, 410 U.S. 113 (1973).

However, during the eight years between Griswold and Roe the concept of privacy would itself undergo a metamorphosis, developing into the framing discourse of "choice." ${ }^{687}$ The idea of "choice" would thereafter blossom, despite the fact that legal precedents undergirding Roe would undergo a persistent battering, and reduction, that not only contorted the common law tradition of stare decisis ${ }^{688}$ but also brought

686 Ibid.

687 Most recently, the "right to choose" has been used quite effectively by advertising agencies to encourage consumerist activity. Money, power and privilege equate to "choice”; the U.S.S.C. has even equated "money” as a form of "speech.” Please see Buckley v. Valeo, 424 U.S. 1 (1976). This development - among others - has called into question the use of this strategy among women's groups as well as in legal and political philosophy circles.

688 The Latin phrase stare decisi means, literally, "the decision.” It means the holding in a case. In practice, it means that holdings in different cases, each based on a different set of facts, should be 
the United States to the brink of overruling Roe. ${ }^{689}$ The rhetoric of "choice" would also expand, leaving the bedroom and moving towards all things commercial. It would become entrenched in American social and cultural life and schemas, glorifying the individual within American political theory.

In Norway, by contrast, the right to use birth control was in place much earlier than in the United States. Another point of departure between the two countries was that the right to an abortion was legislatively - not judicially - decided and linked very quickly with the right to a "self-decided abortion." As in Case One, the Norwegian debate took place after the American debate; while Norway's sterilization law needed 27 years to be seen in Scandinavian societies, in the second case, the time period was only about 5 years. In 1978, the Norwegian Storting passed legislation allowing abortion throughout the first trimester without having to appear before a committee of officials. A woman was also able to have an abortion after 12 weeks, under specific circumstances and through the use of specific administrative procedure and an appearance before this committee. This law was passed in the midst of profound social and cultural changes similar to those that occurred in the United States. Access to birth control had also been a struggle but it had been won earlier in Norway's history than in America. Thus, in Norway the essential issue - abortion - was seen to crest in 1978, earlier than the assaults on Roe were seen in the U.S.

Case Two is also unique because it allows a dissection of the advantages and disadvantages of a legislatively created right versus a "judge-made" right to privacy. It also allows us to compare laws that were said to benefit women, and ultimately families, and which were initially advocated by women for women. In Case One, no "defective" had any voice in the legislation that was enacted, aside from perhaps the rare individual or institution. ${ }^{690}$ The venue was one of legio-scientific paternalism

unified so as to present a precedent. If one moves beyond the precedent, the facts will need to be distinguished from the previous cases.

689 Please see an analysis of "partial-birth abortion" case in which Kennedy wrote the majority opinion, joining Roberts, Scalia, Thomas, and Alito at http://222.womensenews.org/article.ccfm?aid=3139, accessed February 19, 2008. The only woman on the bench, Justice Ruth Bader Ginsburg, issued a biting dissent from the bench against the male majority. Most Supreme Court pundits would agree that only Justice Kennedy stands between a wholesale overruling of Roe by that Court. Kennedy, born in 1936, began his political life by volunteering to draft a tax-cutting referendum for the California Republican Party for then Governor Reagan. Conversant with international law and continental life styles, Kennedy joined Souter and O'Conner in Planned Parenthood v. Casey in 1992, and also became a "visible defender" of gay rights on the Supreme Court. For an analysis of Kennedy's life, temperment and influences, please see, Jeffrey Toobin, "Annals of Law: Swing Shift" in The New Yorker, September 12, 2005, 51.

690 As one might expect, religious groups did become involved. In the years following 1880, the Roman Catholic Church was busy "struggling to absorb and accommodate" the huge number of Catholics who had immigrated to the United States. The issue of race degeneration through immigration provided only an "indirect confrontation" between the church and eugenicists. But, after 1910 theo- 
and essentialism, combined with factors such as high unemployment and a decrease in the population in Norway. The same could be said of Indiana three decades earlier for slightly different reasons - high unemployment with rapid urbanization and immigration - factors that exposed societal problems, which were then interpreted as "race suicide." Case Two gives an opportunity to analyze what appears to be an opposite case in terms of representations, institutions, identities and discourses as well as the framing of the debates. These two cases, which use countries that are at first glance quite different from one another in terms of country population, history and politics, provide a basis for comparison for legal norm formation. In both cases, I examine the same four co-productionist fields of Jasanoff and how they intersect with the Tuori and Tamanaha models.

Both the United States and Norway, with nationally elected Congress/Parliament and legal systems, are categorized as liberal democracies. Through engaging with the issue of sexual reproduction, these institutions have ultimately made several assumptions about the facts of reproductive biology. These normative assumptions, on the surface, represent the science of reproduction but, by necessity and below the surface, also include normative assumptions about who and what men and women are and should do in life. I need to mention one important assumption here. In the United States and in Norway, a woman is considered to be an autonomous actor. By this, is meant that both men and women, at all times and at all places, until proven otherwise, independently decide whether or not to have sex - without any sort of coercion. Sex is assumed to be a voluntary act. Legally, sex is conducted in a sociopolitical, economic and emotional vacuum. Aside from rape in western legal systems, the responsibility for the possibility of pregnancy usually rests with the woman. One problem with this assumption is, however, that for a woman "sexuality and reproduction are inseparable from each other and from gender." ${ }^{691}$ Gender roles and economic factors are entirely absent from the legal calculus.

Another obvious phenomenon is that the concept of "motherhood" changes from time to time and from place-to-place and this is done at the same time as competing discourses also arise within a given society. ${ }^{692}$ As Allison Diduck notes, a kind

logians began to discuss the moral nature of vasectomies in the pages of the American Ecclesiastical Review, at the same time as birth control became a major issue in American life. In 1916, John Ryan of the Catholic University of America formulated the Chruch's natural law argument against birth control. In 1927, prompted by the USSC's decision in Buck, Ryan also wrote against sterilization saying it was not only "unscientific and bad policy" but also conflicted with the social justice vision of the 1891 encyclical, Rerum Novarum, written by Pope Leo. Please see, Sharon Mara Leon, "Beyond Birth Control: Catholic Response to the Eugenics Movement in the United States, 1900-1950.” unpublished PhD diss., University of Minnesota, 2004, pp. 1, 51, 30, 52, 34.

691 Catherine A. MacKinnon, Towards A Feminist Theory of the State (Cambridge, Ma.: Harvard University Press, 1989), 184.

692 Anthropologist Sarah Franklin has written about this phenomenon with regard to modern for- 
of "shifting hierarchy" emerges and the "dynamics of interaction often include both domination and resistance, so that discourses such as feminism, modern rationality, science, social work and psychology are imbued with race, class and sexuality." ${ }^{693}$

The ultimate tapestry [that] emerges is a law infused with constructs of motherhood interwoven with many different strands. The ideological significance of these dominant constructs and the law which supports them is that they then appear to be natural normal and legitimate. ${ }^{694}$

The stability of this normative legal tapestry is only an illusion, however, as each generation constructs its own dominant ideology that may be "imported and incorporated into law." ${ }^{695}$ For example, in 1907 , discourses existed which talked about the duty not to have children if they could not be properly cared for or were likely to be somehow "defective."

One hundred and eighty degrees later, the dominant legal ideology in the United States changed into that of a conflict between fetal rights and women's rights. What type of home a child grows up in is rarely discussed; race and class play no role whatsoever. To paraphrase the phrase conjured by Anatole France and later referred to by Justice Frankfurter in Griffin v. Illinois, 351 U.S. 12, 23 (1956), poor children have the same right to sleep or play in sewage under a bridge as rich children. The only discourse that seems not to have changed is the demand for better, more "perfect" children from women in a "traditional" (code for married, white, heterosexual, religiously conservative) family setting with "traditional”, i.e. patriarchal values. ${ }^{696}$ To an extent, this type of legally abstracted thinking has been made more contextualized in Norway, linked with relationships and experiences. A woman's social and economic situation is brought to the fore, especially since marriage is not the only basis for parental legal rights in Norway. ${ }^{697}$

mulations of kinship. Please see, Sarah Franklin, "Making Representations: Parliamentary Debate of the Human Fertilization and Embryology Act" in J. Edwards, et al., Technologies of Procreation: Kinship in the Age of Assisted Conception (Manchester: Manchester University Press, 1993), 96-131.

693 Alison Diduck, "Legislating Ideologies of Motherhood" in Social and Legal Studies, Vol. 2, no. 4 (1993), p. 462. This idea supports my use of those same categories in my analysis of the framing of discourses at the micro-level of a state/society.

694 Ibid.

695 Ibid., 480.

696 This 1894 quotation by Anatole France surfaces again and again and was most recently referred to in Linda Lewis v. Grinker (Tommy G. Thomspon), a 2000 case decided in the U.S. Second Circuit Court of Appeals. The case dealt with medical care for pregnant women who are undocumented workers.

697 In Norway, any two persons who co-habitate without benefit of marriage have legal rights similar to those who are married. Today, about $50 \%$ of all births in Norway are born to parents who are not legally married; only $7 \%$ of this number refers to single mothers, living alone. This was reported by Christian Knudsen Sture, researcher for NOVA in his report "The Family in the Norwegian Society", 2006, available online at http://www.uio.no/studier/emnec/hf/iln/NORINTO500/v07/Family-Norwe- 
Case Two is assembled in roughly the same way as Case One with one exception. The Griswold case was not the beginning but at the end of a long line of legal efforts by a social movement organization in the United States. That social movement is a key to an understanding of Griswold. The movement was very active in Connecticut, in the very same area from which Griswold would emerge. It also includes some of the very same actors. With that in mind, I examine the Comstock Law and the Chase Dispensary case before I move onto Griswold. The point is that the structures, schemas and resources that were in place in 1939, the year of the Chase Dispensary Case, had changed by 1965, the year that the Griswold case was decided by the United States Supreme Court.

\subsection{Phase One: The Comstock Law (1873) and its Proponents}

The American portion of Case Two begins and ends - in terms of geography - within a span of nine miles. Estelle Griswold and Dr. Lee Buxton, who were arrested in 1961 for operating a Planned Parenthood Center, lived in New Haven, Connecticut. New Haven is only nine miles from New Canaan, Connecticut, where Anthony Comstock (1844-1915) was born on 7 March 1844. Comstock and his social network were responsible for what are now commonly referred to as the "Comstock Laws", and which was the very same law, albeit in state form, under which police would first arrest members of the Chase Dispensary in New Haven in 1935 and Estelle Griswold and Dr. Buxton in 1961.

Anthony Comstock essentially set the arrest of Griswold and Buxton in 1961 in motion some ninety years earlier. Comstock was an extremely religious person - even for his own day and age. He spent his life in a personal crusade for moral purity - as he defined for himself and as a movement of like-minded citizens also did. Comstock and these citizens claimed to base their opinions, primarily on the Bible. And, there was one type of woman in particular that offended Anthony Comstock. This was a woman who believed in the right to plan the size of her family through the use of contraceptives, or in the right of women to engage in discussions and debate about matters involving sexuality, which inevitably included contraception and abortion. The type of woman who might launch a newspaper entitled "The Woman Rebel"

\footnotetext{
gian, accessed December 29, 2007. If a woman has a child and is unmarried, she is entitled to state benefits. The father of the child also has legal rights and duties as if he were the married husband of the woman. The basic law on married and unmarried heterosexuals who live together and have children can be found in the Law concerning children and parents ("Lov om barn og foreldre (barnelova)") of 8 April Nr. 71981 and its various amendments. The basic law on "partnerskap" for homosexuals is formulated in the Law of Registered Partnerships ("Lov om registrert partnerskap") of 30 April Nr. 40 1993. It is true that the paternity of a child is also legally independent from marriage in the United States, but cohabitation is not as socially sanctioned or the subject of law.
} 
where, on the masthead, was printed the motto "No Gods, No Masters." The woman who actually did launch this newspaper was Margaret Sanger, whom we have met above in Chapter 3. She was the most visible female crusader for reproductive rights at the same time when Comstock sought to enforce his vision of "purity." In short, Sanger embodied the type of woman Comstock considered to be "impure" and as a consequence of that impurity, involved in illegal activates.

Anthony Comstock routinely used the American judicial system to advance his own personal moral belief system. In 1914, Comstock had Margaret Sanger arraigned on eight counts of obscenity for publishing newspaper articles on birth control. He also obtained a conviction against Margaret Sanger's husband, William Sanger, in 1915, for selling a single copy of a pamphlet on birth control entitled Family Limitation. But Margaret Sangerr was a force to be dealt with and would actually survive Comstock to see the birth control movement flourish. Early in life, Sanger became involved in public health nursing and concluded that "poverty, debility and big families went together." ${ }^{698}$ In 1914, she founded The Woman Rebel to advance this idea. Not pleased, churchmen and politicians agitated for the police to swear out a warrant for her arrest, whereupon Sanger traveled to England. In England, she met Marie Stopes (1880-1958), author of the book Married Love and a major force in the British birth control rights movement. Upon her return to the United States, Sanger founded the American Birth Control League (ABCL) in 1921.

Anthony Comstock did not conduct his fanatical movement single handedly. His crusade was empowered by a number of private organizations as well as by the Congress of the United States, both groups possessing varied and numerous resources and expressing belief in the same schemas. Congress allowed Comstock onto the floor of the House of Representatives in January 1873, where he remained nearly all day. Carrying a satchel full of books and pictures he claimed were pornographic, he showed them to every member of Congress he could buttonhole, and lobbied for a bill that would give him the legal authority to carry on his campaign of persecution and censorship in the name of fighting obscenity. One biographer notes that tears flowed from his eyes as he addressed Congress, begging for a law to stop the "hydra-headed monster" of vice. ${ }^{699}$

Congress was impressed with Comstock's personal lobbying and passed what was known as the Comstock Act. This act made it a crime to advertise or mail not only "every lewd, lascivious, or filthy book, pamphlet, picture, paper, letter, writing, print, or other publication of an indecent character", but also any information "for preventing contraception or producing abortion." Congress passed this law with virtually no

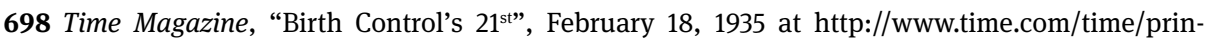
tout/0,8816,748484,00.html, accessed February 6, 2007.

699 Helen J. Self, Prostitution, Women and the Misuse of the Law: The Fallen Daughter of Eve (New York and London: Routledge, 2003), 46. 
discussion, acting by unanimous consent in the Senate and under suspension of the rules in the House. The Comstock Law, in pertinent part, read:

Be it enacted.... That whoever...shall sell...or shall offer to sell, or to lend, or to give away, or in any manner to exhibit, or shall publish or offer to publish in any manner, or shall have in his possession, for any such purpose or purposes, an obscene book, pamphlet, paper, writing, advertisement, circular, picture, drawing or other representation, figure, or image on or of paper of other material, or any cast instrument, o other article of an immoral nature, or any drug or medicine, or any article whatever, for the prevention of conception, or for causing unlawful abortion, or shall advertise the same for sale, or shall write or print, or cause to be written or printed, any card, circular, book, pamphlet, advertisement, or notice of any kind, stating when, where, how, or of whom, or by what means, any of the articles in this section...can be purchased or obtained, or shall manufacture, draw, or print, or in any wise make any of such articles, shall be deemed guilty of a... ${ }^{700}$

Punishment for a conviction under this law was a misdemeanor and, as such, a Court was allowed to give a sentence from 6 months to five years at hard labor and a fine of from $\$ 100$ to $\$ 2000$.

The Congressional Committee on Appropriations then set aside several thousand dollars for a special agent to carry out the Comstock Act, and on 6 March 1873, 1 day before his 29th birthday, Anthony Comstock was commissioned as this special agent of the United States Post Office, vested with powers of arrest and the privilege of free transportation on all mail lines. This enabled him to travel the country arresting and prosecuting those who dared to send any information about contraception or abortion or, for that matter, anything that Comstock himself deemed to be lewd or indecent, through the mail.

As a result of Comstock's crusade, publishers were forced to censor their biological and physiological texts, druggists were punished for giving out information about contraception, and the average American had to live with censorship of his or her mail, without access to reliable information about contraception. Ultimately, the Comstock Laws were overruled at the federal Circuit Court of Appeals level. On 7 December 1936, the U.S. Court of Appeals for the Second Circuit upheld a district court ruling in the case U.S. v. One Package, 86 F.2d 737 ( $2{ }^{\text {nd }}$ Cir.) (1936). One Package held that the 1873 Comstock Law could not be used by the government to seize birth control devices shipped to doctors. ${ }^{701}$ But the Comstock Law would still live on at the

700 U.S. v. One Package, 86 F.2d 737, 739 (1936). A copy of the entire Comstock legislation can be found at Appendix F.

701 See David J. Garrow, Liberty and Sexuality: The Right to Privacy and the Making of Roe v. Wade (New York: Macmillan Publishing Company, 1994), pp. 41-42. The United States is divided into 11 Circuit Courts of Appeal and the second circuit includes the three states of New York, Vermont and Connecticut. 
state level until the 1960s when the demise of Connecticut's little Comstock would mean the demise of it in all other states.

After moving to New York, Comstock began working with the local Young Men's Christian Association, (YMCA). The YMCA had also been active in the same areas Comstock was concerned about and was instrumental in passing an ineffectual antiobscenity law in New York in 1872. Comstock began an investigation of 165 obscene books and found that they all came from four publishers, three in New York and one in Brooklyn. ${ }^{702}$ In order to buy the plates from one of the publishers, Comstock wrote to the Director of the YMCA, R.R. McBurney, asking for money. ${ }^{703}$ The first paid President of the YMCA, Morris Ketcham Jessup (1830-1908), happened to see Comstock's letter on McBurney's desk and, as a result, Jessup then went to visit Comstock. This meeting produced the "most important and longest standing friendship" in Comstock's life. It also gave him access to men with money and power whom he might otherwise never have known and who eventually formed the New York Society for the Suppression of Vice (NYSSV). ${ }^{704}$ After their second meeting, Jessup, through McBurney, sent Comstock the $\$ 650$ that he needed to buy the obscene plates. The dramatic flourish with which Comstock delivered these unsavory plates and books impressed the YMCA and set a theatrical pattern, devoured by newspapers of the time, that Comstock repeated until the end of his life. Comstock worked on a number of fronts to achieve his goals, mainly prevention of "obscenity" through censorship and preservation of "purity" in society at large through a special type of morality in the family. Public censorship and private purity/morality both in the public and private spheres were two sides of the same coin for him.

Just as Dr. H. Sharp and his associates in Case One, Anthony Comstock had access to various, polysemious resources. These resources were tied to the social, religious and financial networks of other men, who like Comstock, had strict (public) schemas of what was "normal" and "not-normal" and who were tied to the institutional structures of the day. However, unlike the local Indianans who supported Dr. Sharp's work, the network that supported Comstock had a larger reach than the band of brother Hoosiers in Case One. I need only mention one member to emphasis this point, i.e. John Pierpoint Morgan (1813-1890).

J.P. Morgan was one of the original founders of the Society for the Suppression of Vice. Morgan was also extremely wealthy; he financed the U.S. Steel Corporation and later arranged a merger of the Edison General Electric and Thomson-Houston

702 Anne Louise Bates, Weeder in the Garden of the Lord: Anthony Comstock's Life and Career, (Lanham, New York, London: University Press of America, Inc., 1995), 59.

703 McBurney's position within the YMCA is ambiguous. He may have been a "director" but he may also have been the treasurer from 1870-1873.

704 Ibid. Please see Appendix A for a list and short biography of some of the original founders of the NYSSV. 
Electric Companies to form the General Electric Company. If that were not spectacular enough, his company bought and reorganized 4 of the 5 major American railways between 1869 and 1899. If Case One demonstrated the social movement at the local level and a society in transition from pre-modern to modern according to Pescosolido, then Case Two demonstrates the effects of a social movement at a national level and in a modern society, using the same dynamics of activity as in Case One.

The wealth of Morgan and the zeal of Comstock combined to both change old societal structures and norms and to create new ones. If Anthony Comstock was anything, he was a zealot of whom the Anabaptist Puritans who landed in the New World would have been proud. In 1892, he was proclaimed to be the "bravest man in New York" by the New York Evangelist. ${ }^{705}$ As Secretary of the NYSSV, it was on his shoulders that "the brunt of all the hard work in breaking up the dens of vice in this city" had fallen. He was portrayed as a hero in the war on vice.

He bears on his face a scar which is to him a badge of honor, as much as the wound of a soldier received in battle, as it was made by the savage cur of a desperate villain whom he was conveying to the place of trial and punishment. ${ }^{706}$

Comstock wrote that there were "three Juggernaut cars of destruction driving through the community, with glittering blades attached to each wheel." ${ }^{707}$ He envisioned these three cars of destruction as aimed at the corruption of "boys and girls of to-day (sic)", aimed at the defilement of American youth. ${ }^{708}$ The three Juggernauts were "evil-reading, gambling and the liquor traffic." ${ }^{\text {709 }}$ To combat the first demanded one search out and destroy obscenity. The second and third Juggernauts demanded abstinence from alcohol and all games of chance, including state lotteries. Comstock himself and the NYSSV advocated this for about fifty years (1850-1900).

While Comstock himself did receive quasi-state legitimation in his job as a Postal Inspector, most of the activity of the NYSSV seems to have been extra-judicial. ${ }^{710}$ As to the NYSSV itself and its goals, its arenas of engagement, the New York Evangelist notes:

But a Society which is a sort of supplement to the Police, and whose agents have seldom to do so as policemen do, literally to knock down and drag out scoundrels, cannot always stand on

705 New York Evangelist, February 25, 1892 (APS Online), 4.

706 Ibid.

707 Anthony Comstock, "The Extirpation of the Crime-Breeders of the Day a Public Necessity" in Belford's Magazine, June 1880 (APS Online, col. 25), 64.

708 Ibid.

709 Ibid.

710 Anthony Comstock, “The Suppression of Vice” in The North American Review, CXXXV (1882), (APS Online), 484. Comstock was a "special agent” or “inspector” of the U.S. Post Office Department, without compensation, beginning in March 1873. As mentioned above, he later received compensation. 
ceremony. It is to be said to its honor that, in spite of all criticism and all opposition, it has gone ahead for twenty years, in the course of which it has suppressed an amount of evil that it is frightful to think of, breaking up gambling dens, policy shops, and the vile holes for the printing and distribution of obscene publications, which have been, in spite of the police, smuggled into the mails and set over the country. ${ }^{711}$

Of course, this religious publication might have been expected to support Comstock and we should consider this opinion with a critical eye. Nonetheless, it demonstrates the three battlefronts on which the NYSSV fought its battles for purity and morality in young souls.

The NYSSV was incorporated by the state of New York on May 16, $1873 .{ }^{712}$ Nicola Beisel has researched the social backgrounds of supporters of the NYSSV and its sister organization, the New England Society for the Suppression of Vice (SSV). ${ }^{713}$ She challenges the assertion that the moral reform movements, as exemplified in the SSV, were "the province of segments of the middle class experiencing erosion of their position in the hierarchies of wealth or social status."714 Instead, she shows that it was the "high white collar" class such as "merchants, businessmen, financiers and professionals" that supported the SSV. Archived articles of the New York Times support this conclusion and the various interconnections among the original sixteen individuals who incorporated the NYSSV. The work of the group was not only carried out at meetings but at the opera, at religious services and at private social events.

It was the rhetorical message of these social structures operating on "several different levels" that supported Comstock's work. ${ }^{715}$ An ideographic analysis of this rhetoric, focusing on "single words, characterizations, narratives, and myths" shows that the word "obscenity" had an extensive and broad meaning that impacted speech about sexuality. In addition to art schools, medical texts did not go unaffected. For example, a Mr. Sherman was arrested no less than three times for publishing his text on the hernia; a jury acquitted him twice but after a Judge instructed the third jury not to consider previous acquittals, Sherman was eventually convicted of circulating obscenity. A previous decision had held that it was "immaterial" if the information was "true and scientifically correct."716

711 Ibid. Adhering to the Fourth Amendment of the Constitution, prohibiting unreasonable searches and seizures, was perceived as "standing on ceremony" in the minds of these zealots. This attitude is mirrored in the current provisions of the so-called Patriot Act.

712 Ibid.

713 Nicola Beisel, Imperiled Innocents: Anthony Comstock and Family Reproduction in Victorian America, (Princeton: Princeton University Press, 1997), 49.

714 Ibid.

715 Marouf A. Hasian, Jr., The Rhetoric of Eugenics ,13-14.

716 Theodore Albert Schroeder, “Obscene” Literature and Constitutional Law: A Forensic Defense of Freedom of the Press (New York: Privately Printed, 1911), p. 338. This book can be accessed at http:// www.archive.org/stream/obsceneliteratu01schrgoog\#page/n343/mode/1up, accessed August 17, 
Comstock's original linkage to the YMCA “and to its leaders by church and neighborhood connections" made Comstock almost invincible. ${ }^{717}$ Horowtiz maintains that without

the New York YMCA behind him, Comstock would have been merely a young clerk informing the authorities about wrong doing, and his career would have been inconsequential. ${ }^{718}$

For example, Comstock's minister was activist William Ives Budington (1815-1879). His neighbor was H.B. Spelman, the father of the wife of John D. Rockefeller. ${ }^{719}$ Comstock also had ties to both temperance and eugenics supporters. In 1897, we read about the Women's Christian Temperance Union plans for a campaign against prize fighting in Buffalo, New York. We find that the Conference on Purity would precede the WCTU sessions in Buffalo by a matter of a few days. At the Purity Conference, under the charge of Dr. Mary Wood Allen, none other than both Comstock and Dr. and Mrs. Kellogg of Battle Creek, Michigan, would assist in the conference. ${ }^{720}$ Sometimes these groups had common members who attended both conferences since they had similar agendas and values that were espoused by one group overlapped with values in another.

While the social movement may have been, as Beisel writes, initiated by white collar elites, the problems that the movement addressed were seen at all levels of society, whether acknowledged or not. Erich Goode and Nachman Ben-Yehuda write that social problems can be manifested at three levels, the grass roots level, the elite level and within an interest group. ${ }^{721}$ The elite-engineered model, according to them, uses major institutions - law, medicine, religion - to "generate and sustain moral outrage" against the deviant group." while probably well-intentioned, are used by the elites, according to Goode and BenYehuda. According to these researchers, the intention of the elite group is not actually to solve the "problem." The intention is to "divert attention away from real problems

2009.

717 Helen Lefkowitz Horowitz, "Victoria Woodhull, Anthony Comstock, and Conflict over Sex in the United States in the 1870s” in The Journal of American History, 87 (2000), 419.

718 Ibid.

719 Ibid. Please see footnote 37. Buddington was also a Christian Commission Delegate.

720 New York Evangelist, (1830-1902), May 6, 1897 (APS Online), 18. The Kellogg breakfast cereal was a peripheral manifestation of the positive eugenics "health" movement. It was touted as having an anti-masturbatory effect. Please see, John Harvey Kellogg, Plain Facts for Young and Old (Battle Creek, Michigan: Good Health Publishing Co., 1892), pp. 320-64. I thank Prof. Sætnan for bringing this to my attention.

721 Erich Goode and Nachman Ben-Yehuda, "Moral Panics: Culture, Politics, and Social Construction”, in Annual Review of Sociology, 20 (1994): 149.

722 Jeffrey S. Victor, "Moral Panics and the Social Construction of Deviant Behavior: A Theory and Application to the Case of Ritual Child Abuse”, in Sociological Perspectives, 41 (1998): 547. 
in a society, the solution of which would threaten the economic and political interests of the elite group." ${ }^{723}$ A cursory look at the names and connections within the NYSSV vis-à-vis the economic problems facing the United States in the early twentieth century, including the power of corporations, would seem to support this notion.

The eugenics movement in the United States had always had a connection with the issue of birth control. Eugenics reformers and birth control advocates tended to belong to the same associations. But, the type of issues that both groups supported appealed to the adherents of some religions and not to others. For example, at the American Eugenics Society and the Eugenics Research Association combined annual meeting in New York on 19 May 1930, Rev. Kenneth C. MacArthur, who was the rural secretary of the Massachusetts Federation of Churches, said that the church needed eugenics. ${ }^{724}$ MacArthur's comments demonstrate two concerns; the burden on churches that had to deal with poverty due to families having too many children as well as the production of a "super race, free of prejudice, ignorance and emotional instability."725

By contrast, some women in the Roman Catholic Church disagreed with birth control, whatever the social price or impact on the individual woman. Denver, Colorado, was the site for the 1930 National Council of Catholic Women where a number of issues were taken up and were passed. One resolution opposed "sterilization of the mentally deficient" and also urged "intensive study of family education to counteract the teaching of birth control and companionate marriage...." ${ }^{\text {726 }}$ The group also opposed beauty and endurance contests for women since they were "unworthy of the high dignity and noble functions of womanhood." 727 It also announced its support for a ruling of the Supreme Court that gave parents the right to decide if their children should attend public or private schools.

But the position of the Roman Catholic Church toward eugenics and birth control had not yet so solidified as to be some sort of a moral tollgate. John G. Murray (18771956) was made the first auxiliary Bishop of the Roman Catholic Church of Connecticut in April of 1920. Not surprisingly, in 1923, he opposed the efforts of the Connecticut reformers to change its little Comstock Law at that time. He testified in the Connecticut Legislature on the bill to allow a "medical exception" for the use of birth control where the life of the women might be endangered should she become pregnant. These remarks have a distinct eugenic edge. He "called for the preservation of the race" and

723 Ibid. What were the problems that SSV work sought to deflect attention from? One need only look to many types of reformist legislation in the 1930s, which ranged from labor laws to pure food and drug laws.

724 Chicago Daily Tribune, May 19, 1930, 19.

725 Ibid. Clarence G. Campbell, of New York, was elected president of the research association at this meeting. MacArthur also advocated the sterilization of alcoholics.

726 Chicago Daily Tribune, October 2, 1930, 31.

727 Los Angeles Times, October 2, 1930, 13. 
said that, unless everyone had at least four children per family, the "races from northern Europe...the finest type of people, are doomed to extinction." ${ }^{728} \mathrm{He}$ eventually followed the Roman Catholic policy on birth control set by the then Archbishop of New York, Patrick Cardinal Hayes. As is sometimes common with various forms of extremism, Hayes set in motion a set of unintended consequences. In 1921, he had the power, even though he was a religious figure, to have the ABCL's first convention raided by police and, in doing so, gave the [American Birth Control League] "a big boost...."729

\subsection{Phase Two: Challenges to Comstock in New Haven (1939)}

Many in the United States felt a climate of dread during the summer of 1939. Despite the fact that the Neutrality Act had been passed by Congress in 1937, on 21 September, six days before Nazi forces crushed the Polish resistance, Franklin D. Roosevelt called a special session of Congress to repeal the arms embargo to allied countries. Earlier, on 14 June, after remarks by the President that Germany's neighbors felt “threatened", Germany offered a mutual non-aggression pact to Baltic and Scandinavian countries which Finland, Sweden and Norway rejected. The United States would eventually become an active combatant two years later on 8 December 1941, after being attacked by the Japanese at Pearl Harbor.

Despite the fact that it would take two full years and an unprovoked attack by Japan to move the United States to enter the war, there was, in 1939, a growing sense in the United States that war was inevitable. Indeed, the Roosevelt government had taken steps to prepare for that eventuality. The first of Winston Churchill's six-volume history of World War Two is called The Gathering Storm and this is exactly the sense one has when reading newspapers from New Haven, Connecticut, in the summer of 1939. In New Haven, the local Italian and Polish immigrant populations received news of the advancing German front throughout Europe, especially in the pages of the The Waterbury Democrat.

In a state that had once been considered mostly the province of Protestant and Congregational churches, Roman Catholic Church membership had doubled in Connecticut between about 1900 and $1930 .{ }^{730}$ On 28 April 1910, Catholicism "came of age" in Connecticut, as John J. Nilan was installed as Hartford's seventh bishop. During his tenure, he concerned himself "with the fostering of many ethnic parishes which

728 Susan C. Wawrose, Griswold v. Connecticut: Contraception and the Right of Privacy (New York, London, Hong Kong, Sydney, Danbury, Connecticut: Grolier Publishing, 1996), 33-34.

729 Time Magazine, "Birth Control's 21 $1^{\mathrm{st}}$, February 18, 1935, at http://www.time.com/ printout/0,8816,748484,00,html, accessed February 6, 2007.

730 Please see Appendix G for data on this. 
would serve Connecticut's diverse population."731 In the 1930's, these Catholic parishes in Connecticut were still divided along ethnic lines.

But ethnically based parishes were not new, even in 1910. Work on St. Patrick's Church in New Haven County began under the reign of Bishop O'Reilly and Rev. Edward O'Brien in the mid-1800s. As early as 1851, the new pastor of St. Patrick's was Rev. James Lynch, a graduate of All Hallows College in Dublin. Lynch built a convent in Middleton for an Irish order of nuns, the Sisters of Mercy, whom he brought from Ennis, Ireland to educate generations of American Catholics. ${ }^{732}$ Germans, on the other hand, gravitated to St. Boniface's Church under Fr. Wendelschmidt in $1868 .{ }^{733}$ The first Italian community began at St. Michael's under Rev. Vincent Asterri. An Italian religious order, the Apostolic Sisters of the Sacred Heart, were "welcomed in New Haven in September, 1906" to begin their work. ${ }^{734}$ Polish Catholics began the church of St. Stanislaus, along with priests of the Polish branch of the Vincentian Order. ${ }^{735}$ Even Lithuanian Catholics had a Church, St. Casimir's, established in $1912 .{ }^{736}$ Since post-bellum times, these parishes had all split into numerous other parishes, especially in response to additional immigration and the birth rate.

Catholic colleges and universities were also founded during this time in New Haven and the vicinity. Jesuits founded Holy Cross College in neighboring Worcester, Massachusetts, in 1843 and Boston College in 1863. Albertus Magnus College, a Dominican college was founded in 1925 in New Haven and the Sisters of Mercy founded St. Joseph College in 1932 in Hartford.

Connections between the Roman Catholic community and the birth control debate in Connecticut are not difficult to find. Some of the leading figures involved in judicial proceedings in 1939 - just as would again happen in 1961 - were Catholic. This is not to say that other religions were not involved, pro or con, but that this religion, more than others, played a major role in the issue. For example, on 4 May 1939, the Waterbury Democrat reported on Father Richard J. Dowling, S.J. the Dean of Education at Holy Cross, giving a lecture to alumni "making a plea for Catholic principles in a world of confusion and upheaval" since only those religiously-based ideas could conquer all problems. ${ }^{737}$ In the audience were State's Attorney William B. Fitzgerald, Attorneys John E. Whelan, Frank MacDonald, Joseph Alishausky, Vincent Scully, Frank Summa, Frank Healy, Judge Edward J. Finn, State Senator Edward P. Egan, Deputy Coroner William B. Hennessey, and Doctors Joseph Reynolds, C.E. Dwyer,

\section{Ibid.}

732 Right Reverend Thomas S. Duggan, Catholic Church in Connecticut (New York City: The States History Company, 1930), 233-34.

733 Ibid., 336.

734 Ibid., 338-39.

735 Ibid., 350.

736 Ibid., 351.

737 Waterbury Democrat, May 4, 1939, 3. 
Walter Keefe, Thomas Welch, Joseph Burke and Alfred Finn. Also in the audience was the Rev. Eugene F. Cryne who would eventually take a leading role in the impending Chase Dispensary battle. ${ }^{738}$

The Waterbury Democrat reported on the activities of Catholic priests with some frequency, in contrast to the New Haven (Evening) Register. Rev. E. Cryne was, in 1939, the pastor of St. Patrick's Church and also the Director of the Waterbury Office of the Diocesan Bureau of Social Service, one of ten such bureaus. He was reported as heading a local delegation to a session of the Diocesan Bureau of Social Services in New Britain in order to hear a speaker, Katherine Lenroot, of the United States Department of Labor. ${ }^{739}$ Edna Mae Maloney, Agnes C. Fitzpatrick and Margaret Tehan would accompany Cryne. The local advisory board for Cryne's Bureau included State's attorney William B. Fitzgerald, who had also been in the audience above. Other board members were attorneys John Gaffney and Frank Healy, Judge Frank P. McEvoy and Doctors Richard Hinchey and Raymond J. Quinn. This would mean that, within the space of 7 days, it is possible that Rev. Cryne would have had contact with Fitzgerald and others twice, first at the Holy Cross alumni dinner and then at the Bureau meeting. If this was a matter of routine, we can assume that the Roman Catholic Church had regular access to members of both the judiciary and the medical profession.

Catholic women had on-going contact with Cryne. Almost every parish had a local equivalent of the of Council of Catholic Women, including Waterbury. Cryne's Bureau of Social Services was located at 56 Church Street where the Women's Council regularly met. In each parish, the local priest would be the Chair of the Committee, which allowed for supervision - and presumably, influence - over the women in the parish and their charitable work. ${ }^{740}$ Members of the Catholic Bureau of Social Services were also well connected in New Haven. For example, attorney Vincent A. Scully, mentioned above, shared offices with John F. McDonough who was elevated from the Naugatuck Burough Court to the local Court of Common Pleas in June. ${ }^{741}$ Judge Edward J. Finn had retired and Governor Raymond E. Baldwin had replaced Finn with John McDonough, perhaps keeping the Irish ethnic group satisfied with his gubernatorial appointments.

Since the early 1920s, the Connecticut Birth Control League (CBCL) had been agitating within the state legislature for a number of years to obtain a "medical exception" for the health of the mother to their "little Comstock law." In 1923 at the Parson's Theater in Hartford, over "800 supporters, mostly women, listened to Margaret

\footnotetext{
738 In 1930, Fr. Cryne was the second resident pastor at St. John of the Cross parish in Middlebury where he was described as watching "with paternal care over the interest of his flock, devoting his spare time to the care of the cemeteries in Waterbury.” Apparently, between 1930 and 1939, Cryne also did organizational work in addition to his care for cemetaries.
}

739 Waterbury Democrat, May 11, 1939, 3.

740 Waterbury Democrat, May 15, 1939, 7.

741 Waterbury Democrat, June 3, 1939, 3. 
Sanger's call to free women from the burdens of childbearing and for legal birth control under medical supervision." ${ }^{\text {"42 }}$ In 1925, these reformers again brought their demand to the Connecticut legislature and gave testimony at hearings on the bill. Along with Sanger was Katharine Houghton Hepburn, a powerful speaker in support of birth control and women's suffrage. ${ }^{743}$ The only opponent of the bill to speak in 1925 was a woman from the Connecticut Council of Catholic Women. ${ }^{744}$

The years 1927 to 1929 were disappointing for birth control advocates. Membership in the national ABCL fell from 13,000 in 1923 to 2,800 in 1926 and the Birth Control Review "had only 47 subscribers in all of Connecticut."745 But, in 1929, after the ABCL had used grass roots organizing to "set up local birth control committees in small towns" the 1929 legislative hearings on the subject were again "raucous, with nearly 1,000 people in attendance." ${ }^{746}$ In addition, the Conference of Congregational Churches in Connecticut also supported the reformers' legislation. The bill was defeated without debate in the Connecticut Senate.

The House was another matter, however, and Representative Epaphroditus Peck, an attorney, forced debate to be held. One female representative spoke against the bill. Her reasoning was that if it passed "only immigrants would contribute to the population growth and girls could become prostitutes." ${ }^{747}$ It was her view that $75 \%$ of girls would become prostitutes. At this remark, there was a "swell of hissing" and she was "silenced as she stood." "448 Despite all this, the bill failed in the House by an overwhelming vote of 226 to $18 .^{749}$ Clearly, legislators were not ready to commit to the idea that a doctor should be able to practice medicine as s/he saw fit when it came to female patients.

In 1930, a decision from the Second Circuit encouraged reformers. In Young's Rubber Co. v. C.I. Lee \& Co., Inc., 45 F.2d 103 (1930), the Second Circuit Court of Appeals $^{750}$ had ruled that, where local laws made it permissible for a doctors to prescribe them, it was not illegal to transport condoms over state lines. ${ }^{751}$ A "doctor's bill" was therefore introduced during the 1931 Connecticut legislative session. Although the Judiciary Committee supported this bill, in an amended form, it was still defeated

742 Wawrose, Griswold, 33. Note 917.

743 Ibid., 34. Hepburn was the mother of the well-known actress.

744 Ibid.

745 Ibid.

746 Ibid.

747 Ibid., 37.

748 Ibid.

749 Ibid.

750 The Second Circuit includes the states of New York, Connecticut and Vermont.

751 Please see, University of Chicago Law Review, 6 (1939), 260. 
in both houses of the legislature despite the fact that the Connecticut Birth Control League had gotten the support of 400 doctors prior to the legislative session. ${ }^{752}$

Given the fact that the Judiciary Committee had supported the bill, there was "renewed enthusiasm and an increase in CBCL [Connecticut Birth Control League] membership." 753 Dr. A. Nowell Creadick, a gynecologist, became leader of the CBCL at this time, and a few days after his assuming leadership, pushed the Connecticut State Medical Society to make a statement of "unanimous support" for the 1931 bill. ${ }^{754}$ However, unlike in Rhode Island, where a birth control clinic had been opened in July 1931 "without incident", Creadick advised against this type of "nullification" tactic ${ }^{755}$, perhaps fearing direct confrontation. In 1933, the CBCL tried again and the House passed the bill with one amendment and that was that the law applied to married women only. The vote was 169 for the measure and 80 against it. However, the Senate rejected it "soundly." ${ }^{756}$ In 1935, a "wealthy supporter" made it possible for a Maternal Health Center to open in Hartford; this center treated women who fit within certain strictly defined criteria and "tested the limits of the statute without outwardly aggra-

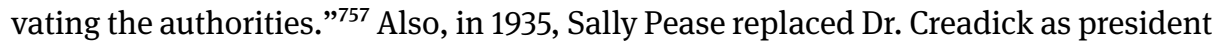
of the CBCL, thus signaling a change in CBCL strategy.

Connecticut authorities did, however, watch the Chase Dispensary, also known as the Hartford Maternal Health Clinic. Despite a report in the press that it had closed, the Clinic did not shut down and even established a number of these Maternal Health Clinics in Connecticut. The CBCL chose not to involve itself in the 1937 legislative session. Consciously or unconsciously, nullification of the law was indeed taking place. Polls in 1936 indicated, "70\% of Americans favored legalizing birth control."758 Additionally, one journal "reported that the mailing of contraceptives was as common

752 Wawrose, Griswold, 38. Note 917.

753 Ibid.

$754 \mathrm{Ibid}$. On the national level, February 1935 saw the sixth attempt by Margaret Sanger to have a federal law passed that would allow doctors to give their patients advice on birth control defeated. As the federal Comstock Law still read, doctors could not give this information without facing the possibility of arrest and/or fine. Time Magazine published a story that included Sanger's reaction to the defeat. Here, it described her as "plump Mrs. Sanger" and noted that, instead of bowing to the will of a male Congress, she held a party to celebrate the 21 years of the birth control movement. Attending the party were “powerful names” such as Mrs. J. Borden Harriman, Mrs. Harold L. Ickes and Mrs. Frederick A. Delano, an aunt to then President F.D. Roosevelt.

755 Here, use of the word "nullification" means that despite the illegality of an act, public support is so strong that the move is supported and is allowed to exist. A similar meaning exists in the law. For example, despite evidence in a trial and despite the Jury Instructions that are given by a Judge, a jury may decide to do the exact opposite of what it is instructed.

756 Wawrose, Griswold, 39-40.

757 Ibid., 40. Women clients had to be married, living with their husband, have at least one child or be "physically or economically unfit for pregnancy" and unable to pay for private care.

758 Ibid., 41. 
as 'the use of gummed postage stamp"' and even the Sears and Roebuck catalog, a staple in American homes at this time, advertised "preventatives."759

In early June 1939, a birth control clinic was reported as operating in the Chase Dispensary. ${ }^{760}$ At first, there was some doubt as to just what exactly the services it provided were. Jeannie Heppel, Superintendent of the Dispensary, told the Waterbury Democrat "a birth control clinic had been operating there since last October."761 Meanwhile, Dr. B. Henry Mason, Superintendent of the Hospital to which the Dispensary was attached, and Dr. Charles Larkin, head of Gynecology, were quoted as saying it was a gynecological clinic and not a birth control clinic. Both stressed that advice was given to women on a "medical basis" when questions were asked; advice was not given to "healthy, normal women." Hepple had also noted that women were seen only upon written referral from their family doctor. But A. "Sally" Morgan Pease of West Hartford had informed the Connecticut Birth Control League on Thursday, 8 June, that there was a birth control clinic that had been operating at the Chase Dispensary. The Democrat noted that Catholic clergy "may" call the event to the attention of Maurice F. McAuliffe, Bishop of Hartford, since "several clinics are reported operating in the state."762

What had actually happened was that the Waterbury Maternal Health Center had begun operation on 11 October 1938 when Nurse Clara McTernan had asked to use two rooms of the hospital for one day a week. The "usual" restrictions on birth control work had been in use, all funding for the work was private and "[m]ost important, the hospital and the center would be distinct entities with no connection."763 In fact, with Sally Pease directing the work, field worker Leah Cadbury and nurse Clara McTernan, had set about to open a birth control clinic in Waterbury at the Chase Dispensary building, attached to the Waterbury Hospital. Two doctors were enlisted; a friend of the McTernan family, Dr. William Goodrich, who had already worked in the Hartford Maternal Health Center and Dr. Roger Nelson were to be the medical team at the Dispensary along with the women. ${ }^{764}$

Sally Pease was enthusiastic about the Clinic. When she spoke to the annual meeting of the Connecticut Birth Control League (CBCL) at the Farmington Country Club, she characterized the new Chase Dispensary at the Waterbury Hospital as one of

759 Ibid.

760 Waterbury Democrat, June 10, 1939, 1. Susan Wawrose notes that the Waterbury Democrat was the "newspaper of choice for much of Waterbury's substantial Roman Catholic population...." Wawrose, Griswold, 46-47.

761 Ibid.

762 Ibid. McAuliffe was ill at this time.

763 Wawrose, Griswold, 46. The restrictions were that birth control services would be given only to married women, living with their husbands who did not have money for private care.

764 Ibid., 45-46. Goodrich was a graduate of Columbia Medical School and Nelson of Cornell Medical School. 
the CBCL's "most important achievements of the previous year."765 The main speaker at the CBLC meeting had been Dr. Woodbridge E. Morris, then General Director of the Birth Control Federation of America where he noted that birth control had had a slow acceptance in America because "apparently we are still mid-Victorian in our thinking."766

Inevitably, the Roman Catholic Church became involved in the matter. Rev. Eugene P. Cryne, whom we have already encountered, was also President of the Catholic Clergy Association of Waterbury. He called a meeting of priests in that group for Saturday morning, June 10, 1939 and by the next morning a proclamation that this group had drafted was read from every Catholic pulpit in Waterbury. ${ }^{767}$ Catholics were told that birth control was against the moral law, that the spread of birth control information was illegal and that they should avoid the clinic. And, on Monday 12 June, this proclamation was printed on the front page of the Waterbury Democrat. ${ }^{768}$

While we cannot know for certain, one Catholic who might have been sitting in one of those pews on 11 June was William “Bill” Fitzgerald, the State's Attorney in Waterbury, whom we have encountered a number of times. If he was anything, he was a quick understudy and had learned that not enforcing a law, however outdated, could be professional suicide. In fact, Larry Lewis, Fitzgerald's predecessor, "had been forced to resign for failing to enforce the state's gambling laws." ${ }^{769}$ Within less than 24 hours after perhaps hearing the sermon, Fitzgerald approached Judge Frank P. McEvoy, also a Roman Catholic, for a search warrant for the Chase Dispensary located on Field Street, and the warrant was granted. ${ }^{770}$ One colleague had described McEvoy as "wildly Irish Catholic" who had "grown up with the teachings of the Church and who was married to an outspoken opponent of birth control."771

The search warrant was executed and within the hour that the search took, numerous "unidentified" articles were confiscated. ${ }^{772}$ County Detective Roland G. Alling and Deputy Sheriff Albert Francis searched the dispensary on Monday morning. In the afternoon, Fitzgerald conferred with Assistant State's Attorney Walter W. Smyth

765 John W. Johnson, Griswold v. Connecticut: Birth Control and the Constitutional Right of Privacy (Lawrence: University Press of Kansas, 2005), 21. The meeting was held on June 8, 1939, a Thursday.

766 Waterbury Democrat, June 12, 1939, 4.

767 The text of this proclamation can be read at Appendix $\mathrm{H}$.

768 Waterbury Democrat, June 12, 1939, 1.

769 Wawrose, Griswold, 47.

770 Ibid., 23. According to Johnson, McEvoy's wife was a "leader in blocking a pro-birth control statement by the Connecticut League of Voters several years earlier.” Wawrose apparantly describes the same inident when, in 1932, at the convention of the League of Women Voters, Mrs. Frank McEvoy, had threatened to leave that organization with all her Catholic sisters if it voted to endorse birth control.

771 Wawrose, Griswold, 47.

772 Waterbury Democrat, June 12, 1939, 1. Detectives made the surprise search shortly before 10:00 A. M. 
and Alling. ${ }^{773}$ Meanwhile, Doctors Larkin, Foster and Goodrich, who had previously refused to characterize the clinic as a "birth control" clinic, did admit that information was given to women whose health "would be 'endangered or seriously impaired' by child-bearing." 774

On 17 June 1939, one week after Deputy Sheriff Francis and County Detective Alling had searched the Chase Dispensary Clinic the Democrat reported that Sallie Pease "welcomed" a court test of the legality of the local clinic. Pease reiterated the League's stand that the laws were "medieval" and that "changing times" required they be reevaluated. Pease issued a statement, which, in part, read:

We are convinced after reading the history of the passage of these laws that they were designed to prevent immorality, and that they in no way touched birth control clinics, which promote the health of families under the supervision of qualified physicians. ${ }^{775}$

Pease ended her statement saying that medieval laws could not "halt the march of progress and health.”

On 17 June a hearing was also held before Superior Court Judge McEvoy, the same Judge who had issued the warrant. This was probably a "show cause hearing" in which Dr. B. Henry Mason and all other "interested parties" were summoned to explain why the seized materials should not be destroyed. Mason did not attend. In his stead, attorney J. Warren Upson (1903-1992) appeared on behalf of the Waterbury Maternal Health Clinic and the Connecticut Birth Control League. He identified the items as the property of the clinic and contested their destruction. Upson asked for a continuance in order to prepare his case and the matter was set over until 3 July. Along with Upson was another attorney, Lawrence L. Lewis, the man who had preceded Fitzgerald in the same job. Upson also identified the officers of the Waterbury Maternal Health Center as Clara McTernan of Columbia Boulevard (President), Mrs. Henry C. Griggs of Tower Road (Treasurer) and Mrs. R.W. Goss of Columbia Boulevard (Secretary). Upson identified this group as "informal in character - with no particular organization.” While this group was not incorporated, the Birth Control League itself was a corporation, whereupon its financial assets and the assets of the Board members could come into play. ${ }^{776}$

The Democrat had reported various aspects of this story for one entire week, on the front page of the paper, with nothing but numerous repetitions of the same facts, making transparent pleas for prosecution and a statewide investigation. But on the

773 Waterbury Democrat, 12 June 1939, p. 1.

774 Ibid., 4. This entire account was indirectly challenged by the Democrat, which reported that Rev. John S. Kennedy, associate editor of the Catholic Transcript, had received a complaint from a Hartford woman, saying that she had been sent unsolicited circulars on birth control work in the area.

775 Waterbury Democrat, June 17, 1939, 1.

776 Waterbury Democrat, June 17, 1939, 4. 
twelfth of June it had new facts, one of which was potentially more interesting than others. Not only had Alling and Francis seized "devices”, they had also seized some records from the clinic. ${ }^{777} \mathrm{~A}$ list of all the seized items had been returned to Judge McEvoy and the items were delivered to the Show Cause Hearing in paper bags and piled on a table in the courtroom. Fitzgerald explained the procedure through which the Clinic had been served with notice of the hearing but also said the Waterbury Hospital had "disclaimed any interest in the articles” at that time. He also cited $\$ 6246$ and $\S 6562$ of the General Statutes of Connecticut, as those laws that were violated by the items. Section 6246 found it illegal for "any person to prevent conception "by the use of any drug or medical instrument" and Section 6762 found it illegal for anyone to assist in contraception. ${ }^{778}$

As a State's Attorney, Fitzgerald had wide jurisdictional powers. He also had several potential defendants to choose from for his indictment. Why did it take him six days to reach this decision as to whom to prosecute? At the time Fitzgerald may have been sitting in the pews of his neighborhood Roman Catholic Church and listening to the proclamation denouncing the birth control clinic on Sunday, June 11, he may not have known that his next-door neighbor - and friend - on Columbia Street, nurse Clara McTernan, was involved with the clinic. ${ }^{779}$ Fitzgerald eventually chose to set any consideration of friendship aside and eventually chose two staff doctors, Roger B. Nelson and William A Goodrich, as well as Clara Lee McTernan as defendants. ${ }^{780}$ The three were arrested on Friday, 23 June after 2:00 P.M. when Fitzgerald obtained warrants for their arrests from Judge Wynne, in Superior Court. All parties orchestrated the time and date of the arrest. ${ }^{781}$ What is interesting about the arrest warrants is that they were obtained so late in the week. Friday afternoons in any Superior Court are likely to be a slow time. Was it possible that Fitzgerald thought he could keep them in jail over the weekend for the lack of a Judge? What we do learn in Monday's Democrat is that Fitzgerald, being a zealous prosecutor, did ask the court that

777 After the first - and only - mention of "files" seized at the clinic, all mention of them stops in the newspaper and the confiscated evidence is described as actual birth control items. One is tempted to wonder if the "files" confiscated implicated some - or even many - working class Catholic families or even of the police officers themselves and upper class Catholics? Any mention of "files" or documents simply disappears.

778 Waterbury Democrat, June 23, 1939, 8.

779 Waterbury Democrat, June 23, 1939, 8. McTernan, said the Democrat, is "identified with the exclusive McTernan School for Boys, on 106 Columbia Boulevard.”

$780 \mathrm{Ibid}$. As it turned out, Fitzgerald soon discovered that he and McTernan were literally neighbors and friends.

781 Waterbury Democrat, June 24, 1939, 3. "Mr. Lewis informed Judge Wynne that the proceedings had been agreed upon.” Dr. Goodrich lived at 138 Grove Street, Dr. Nelson at 161 North Mayn and Clara McTernan at 106 Columbia. 
each post a $\$ 500.00$ bail. But Judge Kenneth Wynne denied Fitzgerald's motion and the three were released on their own recognizance. ${ }^{782}$

We may never know what the personal politics of the Editor of the Waterbury Democrat were or what his idea of unbiased reporting was. Nonetheless, we can make a fairly reasonable supposition about its sympathies on the Chase Dispensary case. On the front page of the Democrat directly adjacent to the birth control clinic story of 23 June, which was the headline story, was an inset of the "Stork Stamp." It showed a woman with children on either side of her. She was looking down lovingly at a newborn child. Apparently, the French government, worried about the declining birth rate, had issued the stamp to depict "the joys of motherhood."783

Superior Court Judge Kenneth Wynne made a decision in the Chase Dispensary Case in early August 1939. The younger Judge Wynne sustained the demurrer ${ }^{784}$ that Upson had filed, which could have ended the case then and there. What we do find out in the newspaper report of these events is that it was attorney Fitzgerald, who wanted to make this a test case and that Wynne, by his upholding of the defense demurrer, gave a "tacit recommendation" to Fitzgerald to take the case to a higher court. $^{785}$

The Democrat cited a lengthy section from Wynne's 25-page memorandum that accompanied his decision. Wynne cited to the Massachusetts Gardner case in which that state's statute, similar to Connecticut's, was upheld by that state's highest court. Wynne also quoted from Chief Justice Rugg of Massachusetts "whose opinions are universally valued and respected."786 Wynne said:

No decent person would deny the laudable objective of morality and chastity, which...[the Gardner case decision] sought. It is, however, common knowledge that many legislators voting against the recognizing of the medical aspect of the problem, appease intellectual integrity by a specious argument that reputable doctors and a respectable married women will not be affected. It is against this easy doctrine of inconsistency that high-minded members of the medical profession have inveighed. Now comes the test. ${ }^{787}$

782 Waterbury Democrat, June 24, 1939, 3.

783 Waterbury Democrat, June, 23, 1939, 1. Placement of the stamp story was, most probably, not an accident. For a more detailed account of the legal maneuvers in the Chase Dispensary Case, please see Appendix I. The stamp cost 80 centimes, 10 centimes of which would go to support the National Alliance for the Increase of the Nation's Population.

784 To sustain means to to uphold as correct after objection by the opposing party. A demurrer is essentially a legal signal meaning "So what?" Upson was saying that if everything the State was complaining of was true, where was the harm?

785 Waterbury Democrat, August 7, 1939, 1 Flush left. It is probable that all parties involved in this case had the same intention, i.e. to make this a test case.

786 Waterbury Democrat, August 24, 1939, 1.

787 Waterbury Democrat, August 7, 1939, 4. 
The very next day, the Democrat reported that sources close to Fitzgerald's office had "hinted strongly today that an appeal would be taken to the Supreme Court of Errors"788 of Judge Wynne's decision. The orchestration of the Chase Dispensary Case was almost complete. ${ }^{789}$ This appeal would stop the defense motion, to be heard in September, to discharge the three defendants. Once the appeal of Wynne's decision had been heard, the entire issue could be decided "once and for all."790

Birth control activists who were part of the larger social movement knew what this strategy meant. Congratulations on Wynne's decision came from all quarters despite the fact that his memorandum basically found that the dispensary had been organized to violate the existing statutes. The general director of the Birth Control Federation of America, Dr. Woodbridge E. Morris, was quoted referring to the "outworn laws" implicated in the case, and said "Physicians of the state are now free to practice medicine.” Mrs. A.W. Pease, President of CBCL, was reported as saying that Wynne's decision was "a great triumph of common sense over a ridiculous Connecticut law." The Vice President of the Hartford league, Mrs. Thomas Hepburn, praised Judge Wynne’s decision as "wise and humane" and the three defendants as having "moral courage in the face of embracing accusations against them when they were performing a valuable service to the City of Waterbury."791

Legal strategy aside, Nelson, Goodrich and McTernan were eventually convicted. Fitzgerald's appeal of Wynne's Demurrer was upheld at the appellate level. Upson appealed the conviction of the two doctors and nurse, which was a decidedly reasonable move, especially in light of the earlier federal decision in United States v. One Package. In a split decision in State v. Nelson et. al., the Connecticut Supreme Court signaled it was in no mood to listen to what the federal government had to say on the issue and, in a 3-2 decision, upheld the conviction. This decision established that the long sought after medical exception in Connecticut could - or would - not be read into the 1879 statute and the conviction of the Chase Dispensary workers was upheld. ${ }^{792}$ But Upson had, if anything, whittled away at the confidence of the Con-

788 The Supreme Court of Errors is the older name for what is now simply ccalled the Supreme Court of Connecticut.

789 Waterbury Democrat, August 8, 1939, 3.

790 Ibid. This is Wynne's language for his memorandum.

$791 \mathrm{Ibid}$. In this case, a great deal of emphasis was focused on the destruction of items that County Detective Koland G. Ailing and Deputy Sheriff Al Francis had taken into evidence when they raided the Chase Dispensary. Included in Wynne's decision was an authorization for the destruction of the items, although McEvoy stipulated that their destruction should wait until after the criminal case had been finished.

792 Waterbury Democrat, June 14, 1939, 1, 26. Please see State v. Nelson, 7 Conn. Supp. 262 (New Haven County Court, 1934), followed by the appeal at 126 Conn. 418, 11 A.2d 859, 129 Conn. 84, and 26 A.2d 582 (1942). 
necticut Court. In his brief he had used as precedent a 1888 Wisconsin Supreme Court Case, for the idea that:

...any citizen of Connecticut may deal with his own body in any way he wants to and it is his natural right to do so if he does not impair any similar right on the part of another citizen. (Emphasis mine.) ${ }^{793}$

Whatever was, or was not, a legal "natural right” would have to wait twenty-six years to be defined.

\subsection{Phase Three: Legal Norm Production and the Right of Privacy}

After the 1939 Chase Dispensary case, the Supreme Court of the United States heard two cases, concerning the same troublesome Comstock law and from the same (troublesome) state - Connecticut. The first centered on a Dr. Wilder Tileston, an obstetrician, whom the Court said had no "standing" to bring his legal action; this was because there was no actual "case or controversy" demanded by Article III of the Constitution. The Tileston v. Ullman, 318 U.S. 44, 63 S.Ct. 493, 87 L.Ed. 603 (1943) case had been legally flawed from its inception since Tileston had asked that court for a "Declaratory Judgment", i.e. for the trial judge to declare the Comstock law invalid. Procedurally, this would have been a "quick and dirty" end to the law from which the state could take an appeal if it wanted. However, nothing related to Tileston's right to practice medicine as he saw fit or as to the patient's right under the $14^{\text {th }}$ Amendment was presented in the pleadings at the trial level. Civil and criminal procedure at that time made more demands on practitioners and the rules demanded that if arguments were not "front-loaded", the higher Courts would not - could not - supply any remedies at the "back-end."

The legal attempt to "fir[e] a heavy broadside" at the Comstock Laws took time and determination - and, the right set of facts and the right combination of Supreme Court Judges. ${ }^{794}$ The next attempt came from three joined cases; they were Poe et. al. v. Ullman, 367 U.S. 497 (1961) (No. 60), Doe v. Ullman (No. 61) and Buxton v. Ullman (No. 62). All three were heard before the Supreme Court in 1960 with a decision issued in 1961. While all three had pretensions at this "heavy broadside", none of them succeeded. ${ }^{795}$ But a "heavy broadside" begins quietly with a great deal of planning and,

793 Obituary for J. Warren Upson, online at http://bronsonlibrary.org/filestorage/33/upson.bmp, accessed January 7, 2008.

794 New Haven Register, 29 January 29, 1961, 31.

795 Poe was argued March 1-2, 1961 before the USSC. Attorneys for appellants were Fowler V. Harper, Harriet Pilpel, Morris L. Ernst and Nancy F. Wechsler for Planned Parenthood Federation of America, Inc., (amicus curiae), Whitney North Seymour for Dr. Willard Allen et. al. and Osmond K. Fraenkel 
in this respect, these three cases helped to prepare for Griswold by teasing out the issues to which members of the Supreme Court might - ultimately - be receptive.

The first case involved a Jane Doe, a New Haven housewife, for whom another pregnancy would be "perilous to life"; the second involved Paul and Pauline Poe, a New Haven couple, who had had three children, each with an congenital abnormality that died soon after birth; and the third case was by Dr. C. Lee Buxton, Professor and Chair of the Obstetrics and Gynecology Department at Yale Medical School as appellant. The first two cases argued that the statutes infringed on their liberty and "put their lives and health in jeopardy" and Dr. Buxton argued that the laws prohibited him from "practicing his profession according to the scientific principles upon which it is based and according to his conscience" thereby depriving him of protection under the $14^{\text {th }}$ amendment.

The Planned Parenthood League of Connecticut (PPLC) was disappointed by the results of the earlier Tileston case, but Estelle Griswold, who became director of the PPLC in 1953, along with New York attorney Morris Ernst, refused to be so pessimistic. Along with assistance from the American Civil Liberties Union plus the energy of thousands of women during what could be called the "winter" of the women's movement - the 1950s - and the willingness of Dr. Lee Buxton, another challenge was brought in May 1960. This second Connecticut challenge brought on board the experience of Yale law school professor, Fowler Harper, and the PPLC counsel, Catherine Roraback. Having "cut his teeth" on the authoritarian antics of Eugene McCarthy, Fowler Harper was ready and able to contend with the government and the Roman Catholic Church hierarchy. Hull and Hoffer make the following assessment from the period after the unsuccessful Buxton challenge.

Even though times had changed in Connecticut, and liberal Roman Catholics called for an end to the church's political campaign against birth control - it pit Catholic against Protestant and made the church into a political actor instead of a guardian of private conscience - the church's hierarchy continued to lobby [against repeal of the Comstock law in Connecticut]... [Fowler] argued, as much against the Roman Catholic church hierarchy as against the state, that the law violated "the right to engage in normal marital relations", which meant the right of married people in their own bedrooms to exercise "a personal freedom or privilege to procreate or not procreate as the individual may desire or as medical factor may dictate."796

On 2 March 1960, oral arguments had taken place before the Supreme Court in Buxton, et. al. v. Ullman, 367 U.S. 497 (1961). The Waterbury Republican carried an UPI wire report about the event and it is here that we get the flavor of the arguments. This report characterized the Justices as “cool” to Dr. C. Lee Buxton's challenge to the

and Rowland Watts for the American Civil Liberties Union (ACLU), et. al., and for the appellees, Raymond J. Cannon, Assistant Attorney General of Connecticut with Albert L. Coles, Attorney General. The case was decided on June 19, 1961.

796 Ibid. 
1879 Comstock law. ${ }^{797}$ Buxton, who had received his medical degree from Columbia in 1940, had joined the staff of the Department of Obstetrics and Gynecology at Yale University Medical School in 1954. He was known as a "gentle crusader" who talked "quietly, often sprinkling his conversation with droll comments." His research concentrated on problems of sterility and he found it ironic that he'd gotten into so much trouble over the problems of fertility. ${ }^{798}$ Unlike many researchers in general, he was reported as liking to spend time with his patients. ${ }^{799}$

In terms of strategic legal procedure, Yale Professor of Law, Fowler "Chick" Vincent Harper (1897-1965), had filed a declaratory judgment action on behalf of Dr. Buxton in which Harper claimed that the Connecticut law did not allow Buxton to practice medicine in that he could not prescribe contraceptive devices for the two woman participants in the case. During the oral argument, the Justices "showered" attorneys with questions, some producing "outbursts of laughter in the usually sedate courtroom." Two things appeared to worry the Justices, one of which was the fact that no one had ever been tried and convicted under the law, according to Connecticut Assistant Attorney Raymond J. Cannon. The other was a problem of proof since, according the Justice Felix Frankfurter, under Connecticut law, wives could not testify against husbands and vice versa, so the likelihood that there would ever be proof that the birth control prescription had ever been used was zero.

Justice John M. Harlan, asked Cannon if the state of Connecticut would use search warrants to see if married couples were using contraception, to which Cannon answered "I don't know." Frankfurter followed up with the statement that it was important for the Court "to know if there can be prosecutions." Harper Fowler tried to make the point that a doctor could be punished for giving advice alone, but some of the Justices "expressed doubt on this point." 800 There was reported to be "some confusion" as to how contraceptives were sold in Connecticut. Chief Justice Earl Warren asked if they were sold in the "ordinary course of trade" and Cannon replied that they were sold in a surreptitious manner. Justice Frankfurter asked if they were sold in a similar fashion to the way liquor was sold under the Volstead Act where one had to belong to club and give "a pass sign." Again, Cannon had to confess ignorance, saying he had "no personal knowledge." ${ }^{801}$ Rather than be misunderstood, Justice Frankfurter retorted, "I wasn't drawing on that."

Confusion also seemed to exist on whether or not the sale of contraceptives was legal depending on the purposes for which they were sold. Harper argued that they

797 Waterbury Republican, March 3, 1961, 1.

798 New York Times, June 8, 1965, 34.

799 New York Times, July 8, 1969, 43 (Obituary).

800 Absent a look at the original pleadings, we are left to wonder if Fowler had included a First Amendment challenge.

801 The Volstead Act, the popular name for the National Prohibition Act, was in effect between 1919 and 1933. 
were legally available for the purpose of preventing disease. But, in response to Justice Charles E. Whittaker, Cannon said that they could not be legally obtained for any reason. Frankfurter, who seemed to be rather engaged in the argument, then asked if they could be bought for a collection since "People collect all sorts of queer things." This apparently introduced a meandering conversation of reminiscences where Frankfurter told Cannon he knew a man who collected matchboxes and another who collected sausage containers. Cannon then retreated to the position that they could be collected "for scholarly purposes."

The Chief Justice again tried to get a succinct answer from Cannon as to whether or not there was a "direct law prohibiting the sale of contraceptives." The state's attorney responded that a man was once fined for selling them from a vending machine but Cannon was not sure what law that was. Frankfurter than asked whether or not the law was based on the "assumption that procreation is the only justification for conjugal relations?...Increase and multiply is the inarticulate[d] purpose of your legislation[?]" 802 To this rather engaged Judge, Cannon gave the rather feeble answer of, "I suppose so." 803

It was Frankfurter who eventually authored the majority opinion in what was a 5-4 decision in favor of the state. Frankfurter ruled the action did not present a genuine case since no one had actually been prosecuted under the Connecticut law. The case was dismissed but it was Harper who later brought his battle expertise to the Griswold case. There, he argued that the $9^{\text {th }}$ and $14^{\text {th }}$ amendments to the Constitution protected a "right of privacy" and that this right also protected other interests in the $1^{\text {st }}, 2^{\text {nd }}, 3^{\text {rd }}$, $4^{\text {th }}$ and $5^{\text {th }}$ amendments. ${ }^{804}$ This was - finally - a winning argument. ${ }^{805}$

\subsection{Scientific Discourses and the "Throbbing Uncertainties of the Cosmos"806}

Dr. Alan Guttmacher (1898-1974), Chief of Obstetrics and Gynecology at Mr. Sinai Hospital in New York, was pictured in the book section of the New Haven Register early

802 Waterbury Republican, March 3, 1961, 1.

$803 \mathrm{Ibid}$. It appears that Cannon was not ready for this oral argument. I was unable to discover if he was a young state's attorney and had been sent as a lamb to the slaughter or if the state thought the case didn't need a seasoned, effective, attorney since it was so confident it would win the case.

804 Harper died on 8 January 1965 before the decision in Griswold was handed down. His was a life dedicated to civil rights, attacking the McCarthy hearings as well as debating right wing politician, William F. Buckley, at Yale in 1954. He held the Simeon E. Baldwin Chair at Yale University Law School. 805 Fowler Harper synthesized a number of currents in American jurisprudence in his argument. However, and this is not meant to detract from his work, it was ultimately a number of liberal judges who would decide - or be persuaded - by the arguments.

806 New Haven Register, January 1, 1961, 10. 
in January. Doubleday had published his new book, Babies by Choice Not Chance, the same month. Guttmacher would become a familiar face in New Haven throughout this period, advocating for the right of contraception. Guttmacher himself had joined the birth control movement in the 1920s as an intern after witnessing the death of a woman from a botched abortion. By 1960, he had already written three other books, Life in the Making, (1933), Into This Universe, (1937) and Pregnancy and Birth, (1957). ${ }^{807}$ Finally, in 1962 he became President of the National Planned Parenthood Federation.

On Friday, 1 January 1960, Mayor Lee of New Haven gave his inaugural address, reported as "appropriately ceremonial and understandably vague" by the Register. The newspaper made less vague statements, saying that the largest problem looming for New Haven was to "return to solid and stable financial standards at City Hall." The municipal budget had to "be put on an even keel." Lee's political career actually began in 1939 when the Democratic chairwoman of the $17^{\text {th }}$ Ward asked Lee to run for alderman in New Haven. ${ }^{809}$ Lee won and joined forces with Max Schwartz "to sponsor many New Dealish proposals, most of which were promptly voted down by older members of the board." 810 His first job had been as a reporter for the Journal-Courier and he was later elected as alderman. Although his manner of practicing politics was a bit unorthodox, it earned him the support of voters. He walked into the job of Mayor in a city he described as "a decaying community." He had publicized the fact that "10,000 disease-carrying rats infested a single street in the center of the city." ${ }^{811}$ In addition to talking about public health problems, he

embarrassed and angered many voters - including some prominent citizens and at least two red-faced city officials - by having the police tow away their automobiles for illegal parking. ${ }^{812}$

807 "Alan F. Guttmacher 2898-1974) at http://www.guttmacher.org/about/alan-bio.html, accessed May 30, 2006.

808 New Haven Register, 3 January 3, 1960, p. 18.

809 Saturday Evening Post, 19 April, 19, 1958, p. 115.

810 Ibid.

811 Saturday Evening Post, April 1958, 31.

812 Ibid. The Saturday Evening Post, portrayed Lee as a man on a mission. The Post showed a picture of him in front of a new construction site that had been a former New Haven slum. What Lee had inherited politically from the federal government was the National Housing Act, designed to "lend money to buy and clear blighted areas for resale to private investors and [which] would make grants to cover two thirds of the net cost." Lee also "hounded" property owners for back taxes, abolished "patronage jobs", fired some city workers for "loafing" and "waged a long running battle with the town's only newspaper owner, John Day Jackson”.... In November, 1960, he had won re-election by a "record breaking plurality" of 23,000 votes. The 42-year-old Lee, who had never attended college, was described as "tightly wound" but with an "informal manner." Lee was Roman Catholic and during his political career, the New Haven Register ccontinually fought his reforms. Nonetheless, in April 1958, he looked quite "impressive" to the Post which claimed he was "[s]aving a 'dead' city." 
Given the corruption scandal associated with Mayor Hayes in 1939, the fact that one could no longer "fix" a parking ticket signaled a new era for New Haven residents who had experienced the earlier periods.

The editorial page of the New Haven Register wished its own Governor Abraham Ribicoff well as he left Connecticut to join President Elect John F. Kennedy's Cabinet. It predicted a "problem-strewn path" for the Lt. Governor, John M. Dempsey, who would succeed Ribicoff as Governor of Connecticut. ${ }^{813}$ Kennedy himself faced a "politically divided government" with the Democratic Executive and Senate matched by a Republican House of Representatives. The newspaper called for "political honesty" and the "need for statesmanship above party maneuver." But the tone of the New Year's Day editorial in the New Haven Register was a bit subdued and the voice was inward looking as it said:

But lofty musings about the condition of men and alarmed analyses of the political, the economic, or the spiritual failings of this generation are unlikely to produce more results than could be produced through a greater self-knowledge on the part of each of us. So let us today put aside the madness of governments, the contradictions of science, the paradoxes of geography, and the throbbing uncertainties of all the cosmos, to think a moment about ourselves - to weigh the measure of good that we achieve, the measure of love that we dispense, the measure of truth that we defend. ${ }^{814}$

The lofty rhetoric this Editor uses could mean s/he was still under the spell of the national election held in November of 1960, a hard-fought battle that most citizens, particularly in the South, instinctively knew would begin a social revolution.

The social character of the New Haven community in the early 1960s can be analyzed in various ways. However, one interesting detail is found in early January, with a Westbrook dateline. ${ }^{815}$ A woman was reported as shopping in a New York department store and gave her mailing address to the clerk as "Westbrook, Connecticut." The clerk responded "not THE Westbrook?" Westbrook had apparently developed a reputation as a "Peyton Place." Naval Base in Illinois, corroborated the reputation by reading a "lurid account" in a Chicago paper about his hometown. ${ }^{817}$ The report hypothesized that the suicide of a First Selectman in March and the discovery of embezzled municipal funds in April of the previous year accounted for the reputation. In short, the social fabric of schemas

813 New Haven Register, January 1, 1961, 10.

$\mathbf{8 1 4}$ Ibid.

815 Westbrook, Connecticut is less than 30 miles east of New Haven.

816 The reference to Peyton Place, a city located in New Hampshire, may be from the 1957 movie by the same name, staring Lana Turner, Lee Philips, and Hope Lange. Later, in 1964, Peyton Place became a TV series and the name is generally associated with places where the inhabitants have two types of values, one set in private and one set in public.

817 New Haven Register, January 1, 1961, 1. 
claimed to be unchanging and immutable was unraveling as the hypocrisies of that time were being reported. On the other side of the Atlantic, Norwegians would candidly call this type of activity, the "double morality."

On 24 January Dr. Alan F. Guttmacher whom we have encountered above, gave a talk at the Yale-New Haven Medical Center to a capacity audience. Guttmacher was reported as advocating that "'contraception should be taught in high schools and colleges' along with other sex instruction in order to have an informed populace."818 Guttmacher had a dual appointment and was also at that time a Clinical Professor at Columbia University. He urged the United States to adopt "legal programs" such as those "undertaken in countries such as Sweden and Japan" so that the population problem might be addressed. The health of the mother should, according to Guttmacher, "serve as a ground [for an abortion] as well as her life" and that additional grounds such as "eugenic consideration, pregnancies occurring from rape, and socioeconomic reasons." He also noted it was "most illogical” to provide for public health services such as immunizations while doing "nothing about conception control." As for religion, Guttmacher said that the attitude of one religious group toward the issue of contraception should not be "forced upon another [group]."

The Register made information about legal assaults on Connecticut's 1879 birth control ban well known. In late January, it reported on the challenge brought by Planned Parenthood, the ACLU and a group of university obstetrics and gynecology professors; this was the Harper and Rorabeck team mentioned above who would soon challenge State Attorney General Albert Coles. ${ }^{819}$ While Protestant church authorities approved of artificial contraception, the Roman Catholic position was that this was "contrary to divine law." The Register did report that one - more liberal - "Catholic publication" had written that a "Catholic can justifiably favor repeal of the Connecticut and Massachusetts anti-contraception laws, or breathe happily if they are declared unconstitutional." 820

Furthermore, Comstock's ghost was still present and active in Connecticut. For example, in 1961, two women's groups, the West Haven Junior Women's Club and the Connecticut State Federation of Women's Clubs, Inc., resurrected the fight against "obscenity." At the head of this drive was Mrs. Roger Addil of Orange who urged public support for a U.S. Senate Bill that would create a "Federal Commission on Noxious and Obscene Matters and Materials.” The bill had been introduced on 4 January with the support of 22 Senators. The 17-member Commission was envisioned as an "investigative agency" with subpoena power that would report directly to the President. ${ }^{821}$

818 New Haven Register, January 25, 1961, 6.

819 This case was Griswold v. Connecticut.

820 New Haven Register, January 29, 1961, 31.

821 New Haven Register, February 5, 1961, p. 16. In the same issue of the Waterbury Republican, the issue of women being allowed in bars to drink alcohol was discussed. Miss Margaret O. Gray of the 


\subsection{The "Usual Suspects", the Institutional (Religious) Field and Griswold}

The annual meeting of the Advisory Board of the Catholic Diocesan Bureau of Social Services was held on 12 March 1961 in Hartford. The speaker was the assistant executive secretary, Richard Mastronarde, a graduate of the University of Connecticut's School of Social Work, who spoke on the topic "Trends in Family and Child Care." ${ }^{822}$ From the list of those attending, we can see that at least some of the individuals who had been involved in the 1939 Chase Dispensary case were there. The Rev. Eugene P. Cryne was still involved with the organization, this time as Associate Director of the Bureau and Frank T. Healey was President of the Board. The intervening 23 years had been kind to both men; Cryne had been elevated to Monsignor or "Rt. Rev." and Healey had become a Judge. The Bureau was also having financial problems at this time. ${ }^{823}$

Women's Christian Temperance Union (W.C.T.U.) of Connecticut claimed to want to "keep a feeling of respect among our fellow citizens" by arguing against women being allowed into bars. She advanced her particular version of the history of previous years saying, "I saw plenty of what went on in those days." (Waterbury Republican, March 1, 1961, 13.) What was at issue was, literally, a matter of physical distance. In 1961 a woman could drink at a table, if tables were present, but was not allowed to drink at the bar. Women who did drink at the bar were commonly referred to as "B-girls", "usually working on a commission from the management, and encouraging male patrons to buy her and themselves more drinks than they actually intended to buy." (Ibid.) The legislature had heard arguments, pro and con, on the question of "Is it right for women to do their drinking at a bar?." The review of the entire issue was possibly due to support from the Associated Restaurants of Connecticut and the Connecticut Hotel Association whose lobbyist, attorney Stephen Sweet, said that the law was "an old blue law that's been on the books long enough." (Ibid.) On Sunday, the Republican ran a cartoon by "Mort" on the editorial page with the caption "A Bar Flyess." At the bottom of the cartoon was the sentence "Bill in Legislature Would Allow Women To Sit at the Bar." (Waterbury Republican, The Sunday Republican, March 5, 1961, 6.) The cartoon itself pictures a man and a woman at a bar with a bartender behind the bar. The man is dressed in hat and coat and is smoking. He is turned to look at the woman, who is clearly meant to be drunk. Her purse is on her arm but open. Her glass is in the process of being tipped over. One shoe is off and one is curled around the barstool. She is saying, "My husband doesn't understand me." My interpretation of this is that "Mort" is saying women should be allowed to be bar "flyess's" and repeat the same self-pitying phrases that male bar flys are often hear to say.

822 Waterbury Republican, March 11, 1961, 2.

823 Ibid. Assistant Associate Director Rev. John G. Fanning and Attorney James F. Henebry, Chair of the Finance Committee discussed these problems. James F. Henebry (1913-1992) was also born in Waterbury and practiced law there after receiving his law degree in 1940. He served as a trial judge from 1967 to 1992; he was elevated to the Court of Common Pleas in 1975 and to the Superior Court in 1977. (Please see, Obituary Sketch of James F. Henebry at: http://www.cslib.org/memorials/heNEBRYJ. $\mathrm{htm}$ acessed on January 7, 2008. His "most memorable case" was the jailing of 70 Bridgeport teachers involved in a 1978 teachers' strike.) Others at this meeting included several staff members, the Chairman of the Nominating Committee and the President of the Waterbury Council of Catholic Women, Mrs. Charles A Wolisschlager. 
Superior Court Judge Frank T. Healey had again been elected President of the local Diocesan Bureau of Social Services at the meeting mentioned above. Also elected were James F. Henebry, First Vice-President, Carmen Donnarumma, Second Vice-President, Miss Mary Schmidt, Secretary, Rt. Rev. Msgr. Eugene P. Cryne and Assistant Treasurer, Rev. John G. Fahning. ${ }^{824}$ Mastronarde had concluded in his talk that the trend in Catholic childcare was to treat fewer children but ones with more specialized needs, such as the emotionally disturbed. In 1959, the Bureau had given services to 566 children; in 1960 that number had increased to 618. According to Dist. Secretary Agnes F. Brovick the increase was due to "troubled family relationships", such as divorce, separation and mental problems. ${ }^{825}$ The number of unwed parents had also increased. She noted there had been an increase in "applications around prenatal and postnatal services for mothers of out-of-wedlock children."826

Judge Healey was a very active in Catholic organizations in the county. In May, he was re-elected to the Board of Trustees of the Diocesan Bureau of Social Services for the Archdiocese of Hartford at its annual meeting. ${ }^{827}$ In 1939 during the Chase Dispensary Case, Healey had been an attorney working at a general practice in Waterbury. He worked there for 14 years after having graduated from Yale Law School in 1925 and before he was elevated to the bench. According to his obituary, Healey always remained a hometown boy. ${ }^{828} \mathrm{He}$ was a "representative of an old and respected Irish Catholic family.” As the reporter wrote:

This fact is mentioned because Judge Healey would have wanted it so. He never left anyone in doubt about the fact that he was of Irish descent, and he was an almost militant Roman Catholic. He was proud of both distinctions. ${ }^{829}$

Jesuit priest Robert F. Drinan (1920-2007), at that time Dean of the Boston College of Law, also spoke at this meeting on the high divorce rate and methods of lower it. ${ }^{830} \mathrm{Rt}$. Rev. Msgr. George M. Grady noted that, in 1960, the Bureau had served 3,944 families using expenditures of $\$ 782,672$. Hard-to-place children were discussed as well as the fact that the Bureau "continued to work closely with public agencies both at the local and state levels." ${ }^{831}$ The Board of Charities was facing different schemas such as more

824 Spellings of of the surnames Cryne and Fahning vary from article to article.

825 Waterbury Republican, March 12, 1961, 12.

826 Ibid. The agency also had 15 boarding homes at its disposal during 1960.

827 Waterbury Republican, May 8, 1961, 3.

828 Connecticut Reports 150, 733-35 as found at http://www.cslib.org/memorials/healeyFT.htm, accessed on April 23, 2014.

829 Ibid.

830 Drinan would go on to be elected as a Representative to Congress from the state of Massachusetts, serving for ten years between 1971 and 1981. Pope John Paul II then forbade him to continue as an elected Congressman.

$831 \mathrm{Ibid}$. Those attending included Attorney James Henebry and members of the Waterbury Bureau. 
babies born "out-of-wedlock" and a rising divorce rate, even among Roman Catholics. That society in general, and Catholic society in particular, had changed, was obvious.

These two authoritative figures had been at the same (figurative) table in 1939. In 1961, in terms of the Roman Catholic Church as an institution, the same normative institutional structures were still in place as had been in 1939; women did the dayto-day administrative work while the male hierarchy held decision-making positions within the group. But this would soon change. It would not be long before another generation of Roman Catholic faithful would occupy those chairs, a generation that had felt the winds of change in the Roman Catholic Church set in motion by Vatican II (11 October 1962-8 December 1965) as well as the Civil Rights Movement and the Women's Movement, among others.

Between the major "failed" birth control cases, social structural and schematic changes of tectonic magnitude had taken place. Decades of grass roots organizing combined with experience gleaned from less fruitful legal action, plus the energy of Estelle Griswold and Lee Buxton and the strategic legal insight of Fowler Harper combined to finally create a successful legal case from Connecticut. The method of change would be different from Case One; this time, the law would be "judge-made" rather than legislatively formed.

The set of facts underlying Griswold were set in motion in July of 1961 when Estelle Griswold, executive director of the New Haven Planned Parenthood Clinic signed a lease for 79 Trumbull Street in New Haven on behalf of the Planned Parenthood League of Connecticut. ${ }^{832}$ The hopes of these progressive women who had rented the New Haven Planned Parenthood Clinic were to be tested when one James Morris, a Roman Catholic by religion, and the married father of five children, complained to the police about the clinic. ${ }^{833}$ Pictures exist of Morris - alone - picketing the Clinic with a sign reading "ThE Law is The Law OR is it? Morality is in danger!" 834 It took only five months for events to unfold so that, after the issuance of a warrant on 10 November, Estelle Griswold and her clinic medical director, Dr. Lee Buxton, presented themselves to detectives John Blazi and Harold Berg to be arrested with warrants that had been procured by circuit court prosecutor Julius Maretz. ${ }^{835}$ Estelle Griswold was the energetic executive director of the New Haven Planned Parenthood Clinic who had signed a lease for 79 Trumbull Street in New Haven on behalf of the Planned Parenthood League of Connecticut in July of $1961 .{ }^{836}$ Dr. C. Lee Buxton remembered that he and Mrs. Griswold had been called by the prosecuting attorney and asked "how we'd like it done", in reference to the arrest. He was asked if he'd like a paddy wagon

832 Wawrose, Griswold, 82-83. Note 917.

833 Ibid., 10, 85.

834 The typographic irregularities reflect Morris' own spelling and punctuation.

835 Wawrose, Griswold, 85.

836 Ibid., 82-83. Note 917. 
sent "with policemen and photographers...or would we prefer to turn ourselves in quietly." 837

Meanwhile, Griswold, worked its way through the state courts to the federal Supreme Court and on June 7, 1965, Justice William O. Douglas issued the opinion of the Court, which declared the law under which Griswold and Buxton had been arrested as unconstitutional. ${ }^{838}$ Reactions to the Griswold decision differed. Rather flippantly, Dr. Buxton remarked to a friend that, "considering all the trouble that the [Griswold] case had caused him, the judge who convicted him could have at least fined him more than \$100." 839

Griswold v. Connecticut, 381 U.S 479 (1965) was a 7-2 decision of the United States Supreme Court and the author of the decision was Mr. Justice William O. Douglas. At the time, Douglas had been a Supreme Court Justice for four years, having been appointed by J.F. Kennedy on 1 October 1962 as a replacement for F.D. Roosevelt's appointee, Felix Frankfurter, of One Package fame. Justice Tom Clark, who had followed all things concerning birth control over time as a Clerk of the same Court, joined Douglas in the majority decision. Concurring in the outcome, but not necessarily the reasoning, were Justices Goldberg, Warren, Brennan, Harlan and White. Justices Stewart and Black cast the two dissenting votes.

Griswold had come before a Court that was mainly liberal in its leanings. Arthur Goldberg, a labor lawyer, had been added to the Court in September 1962 serving until 1965. Earl Warren (s. 1953-1969), unlike in Poe, had a transcript of the trial of Griswold and Buxton and could not therefore claim there was no "real controversy." He "would have preferred" that the Connecticut legislature had done its own work and had struck down the statute, but he did think it was "overly vague - the narrowest possible grounds for voiding it." ${ }^{840}$ Justice Harlan was in ill health but vigorously opposed the birth control law and Brennan, a devout Roman Catholic, was of the same opinion. Byron R. White, who had been a Deputy Attorney General under J.F. Kennedy, had replaced Justice Charles Whittaker. Only Justice Potter Stewart had qualms. In $\underline{\text { Poe, }}$, he'd been willing to base a reversal on the $14^{\text {th }} \mathrm{Amendment}^{841}$; it was

837 New York Times, July 8, 1969, 34 (Obituary).

838 Ibid., 99.

839 New York Times, June 8, 1965, 34. The fact that Estelle Griswold and C. Lee Buxton were convicted and fined is history that some have forgotten, never learned or conveniently overlooked. On Fox News’ Special Report, 24 October 2005, host Brit Hume claimed that no one had ever been prosecuted under Connecticut's "little Comstock Law” before Griswold was decided, to which Douglas W. Kmiec, constitutional law professor at Pepperdine University, responded "That's right. This was largely a test case, although it was a criminal statute, and they could have been subject to fine and imprisonment." Please see, http://mediamatters.org/items/printable/200510270006, accessed January 7, 2008.

840 N.E.H. Hull and Peter Charles Hoffer, Roe v. Wade: The Abortion Rights Controversy in American History (Lawrence, Kansas: The University Press of Kansas, 2001), 83.

841 The $14^{\text {th }}$ Amendment to the Constitution, ratified after the Civil War in 1868, includes 5 sections. 
one thing to declare a statue illegal based on an actual, existing Amendment but it was another to find a right that didn't even exist in plain language in the Constitution.

William O. Douglas had two problems that he had to deal with in the writing of his decision. The first was that the federal Constitution includes no reference to marital (or any other form of) privacy as such. The second was that there was a long-standing policy that the Court would not interfere in a state's attempt to regulate "public morals." This had been so with regard to the use of alcohol, gambling, homosexuality and sex crimes. Douglas took his cue from Fowler Harper's briefs. In fact, according to some, Harper was the "author of the right to privacy." 842 This is not unreasonable, as Harper, along with his Yale colleague Fleming Jones, had written a multi-volume treatise on torts, the subject where speculation about a right of personal privacy would most likely take place. However, the development of the "right to privacy" is a bit more complicated.

Since Fowler Harper was terminally ill when the briefs had to be submitted to the Supreme Court, his Yale colleague, Thomas Emerson, "framed the final brief and argued it before the Court." ${ }^{843}$ A law review article written by law professor Norman Redlich had influenced both Harper and Emerson and they chose to make the right of privacy the centerpiece of the brief on behalf of Griswold and Buxton. One could say, as Hull and Hoffer do, that Emerson's final brief "waffled" as to where the right could be found; one could also say Emerson gave the Court a choice, overlooking no possible source. ${ }^{844}$ This approach garnered support from some quarters, even within the Catholic Church. The Catholic Council on Civil Liberties filed an amicus curiae brief in support of Griswold and no less than Cardinal Richard Cushing of Boston agreed to the move. ${ }^{845}$ This again supports the notion that the Roman Catholic Church of the early 1960s was not the monolithic institution with one, absolute, singular interpretation on issues that the Vatican, largely during the papacy of John Paul II

It was a fundamental addition to the Bill of Rights and provides a definition of citizenship (Section 1), ante-bellum representational apportionment (Section 2), exclusion from office for those involved in an insurrection (Section 3), payment of debts incurred during an insurrection (Section 4) and a promulgation section (Section 5). The most salient feature of the $14^{\text {th }}$ amendment lies in Section 1 , providing "due process" and "equal protection" under the law to all persons - not only citizens of the United States. Section 1 has been used to overturn the Dred Scott case as well as argue against segregation in Brown v. Board of Education. (But see Roberts in Parents Involved in Community Schools v. Seattle School District No. 1, 551 U.S. 701, 127 S.Ct. 2738, 75 U.S.L.W. 4577 (2007).) It was used in $\underline{\text { Roe v. }}$ Wade as well.

842 Please see: http://www.law.onu.edu/about/Fowlerharper.html, accessed on January 7, 2008. Homepage for the Ohio Northern College of Law.

843 Hull and Hoffer, Roe, 83.

844 Ibid.

$845 \mathrm{Ibid}$. Cushing went so far as to support a Massachusetts bill that would repeal their anti-birth control legislation. Hull and Hoffer, Roe, 83. 
(r. 1978-2005), and Benedict XVI, and later imposed on the American Roman Catholic hierarchy as well as devout believers.

Douglas argued that the right of privacy is created by the $1^{\text {st }}, 3^{\text {rd }}, 4^{\text {th }}$ and $5^{\text {th }}$ Amendments to the Constitution. The $1^{\text {st }}$ Amendment is commonly referred to as the granting the "right of association", the $3^{\text {rd }}$ prohibits the State from housing soldiers in one's house in time of peace, the $4^{\text {th }}$ Amendment protects citizens against unreasonable searches and seizures and the $5^{\text {th }}$ Amendment does not allow the State to compel testimony against oneself. Because Douglas worried about a "plain meaning" or "specific intent" argument, he leaned on the $9^{\text {th }}$ Amendment which says that "The enumeration in the Constitution, of certain rights, shall not be construed to deny or disparage others retained by the people."

Justices Goldberg, Warren, Brennan and Harlan, in the main, agreed with Douglas on the first issue of where a right of privacy can be derived. When writing about the second issue, they found the right of privacy as "fundamental" thus demanding the highest level of scrutiny, "strict scrutiny." Justice Potter Stewart, a Republican appointee to the Court, dissented; he could find no such language in the Constitution as a "right to privacy." Nonetheless, he called the Connecticut law "asinine", "unwise" and "uncommonly silly." In other words, the state was free to pass as many silly laws as it wanted, and they may be legal, as long as the Constitution said nothing about it. Stewart's reasoning is a perfect example of a contextualization or, the view from nowhere. The fact that women had died as a result of just such abstract reasoning was of no moment to an "originalist” Justice such as Stewart.

The precedents that Douglas used were more than forty years old and did not even use the word "privacy." These were Pierce v. Society of Sisters (1923) and Meyer v. Nebraska (1923). Pierce dealt with an Oregon law that sought to compel every child to attend public school. Meyer dealt with a law forbidding the teaching of any other language than English to schoolchildren below the eighth grade. At issue was the teaching of German. What Douglas was doing was using legal reasoning to argue that "confidential relationships" in Pierce and Meyer were similar to the confidential relationship between a husband and wife. ${ }^{846}$ While it might be difficult to imagine that what language one speaks or where one's child goes to school could be similar to the communication between husband and wife in the marital bed - aside from their location in a "private sphere" - it demonstrates two things: first the lengths to which Douglas was willing to go to find precedent to support his unique argument and second, the paucity of cases with facts that dealt with husband-wife communication on sexual matters.

When it came time to vote on Douglas' opinion, there were only four votes Douglas himself, White, Goldberg and Harlan. If the opinion had five votes, it could be said to be the "decision of the (entire) Court." Brennan and Warren chose instead

846 Hull and Hoffer, Roe, 84. 
to concur with Goldberg's opinion since it embraced the $9^{\text {th }}$ Amendment as a source of the privacy right. Goldberg had assigned a clerk, Stephen Souter ${ }^{847}$, to research the origins and purpose of the 9th Amendment. Souter found that James Madison, the "principal architect of the Constitution as a whole", had written the amendment and it had been passed by both houses of Congress with little debate and no changes. ${ }^{848}$ Congressmen were afraid that the first eight Amendments might not have been "comprehensive enough to secure the rights and liberties of Americans." 849 The $9^{\text {th }}$ Amendment, according to Goldberg, made allowance for additional rights that the original framers had not envisioned. Goldberg wrote that "the language and history of the Ninth Amendment reveal that the framers of the Constitution believed that there are additional fundamental rights, protected from government infringement, which exist alongside those... specifically mentioned in the first eight constitutional amendments." ${ }^{850}$ Despite Goldberg's citation to James Madison for the $9^{\text {th }}$ Amendment as a source for legal privacy, Justice Black found no such right in the same set of words.

Justice White's argument is worth noting. He thought in larger concepts - but not as large as "privacy." For one, he was concerned that he had often "berated his colleagues for reintroducing substantive due process" in criminal matters. ${ }^{851}$ For another thing, White was concerned about the subject matter of the Connecticut law itself, "its interference with marriage." ${ }^{852}$ States had to show, if their laws were to intrude upon a "fundamental" constitutional right, that their law was based on a "compelling state interest", and not "merely related to a legitimate government interest." States would often argue that their laws against birth control were related to the deterrence of "illicit sexual relationships like homosexuality, adultery, and incest", as if combining all these groups together would make the arguments too loathsome to listen to and thereby produce a knee jerk reaction - against proposed birth control law. ${ }^{853}$ Justice White had a problem with such reasoning, however. He saw no relationship between birth control information and deterring adultery or homosexual activity.

In the end, Justice William O. Douglas' opinion was published but it was not a decision of the entire court. Accompanying it were three concurring opinions. ${ }^{854}$ The

847 Souter was appointed to the Court in 1994.

848 John W.Johnson, Griswold v. Connecticut (Lawrence Kansas: University Press of Kansas, 2005), 171.

849 Ibid.

850 Hull and Hoffer, Roe, 85.

851 Ibid., 86.

852 Ibid.

853 Ibid.

854 A "concurring" opinion is one that agrees with the holding of the case by the Justice who writes the opinion for the majority. A concurring opinion usually approaches the legal problem presented somewhat differently, oron other legal principles, but nonetheless agrees in the holding. 
first, by Arthur Goldberg, was joined by the Chief Justice, Earl Warren, and William Brennan. Harlan wrote the second concurrence; Byron White wrote the third concurrence while Black and Stewart wrote the two dissenting opinions.

\subsection{Rapid Social Change and Intersectional Categories}

What changes were occurring in and between the larger social structures in the United States at this time? As the United States Congress convened on 6 January 1960, eleven months before the national presidential election, the two most "explosive issues" were civil rights and federal aid to education, according to the New Haven Evening Register. ${ }^{855}$ One might have thought that World War II and its aftermath might have prompted changes in normative practices as regards racial minorities. Women had taken the jobs of men in various industries during the war and one might also have thought the normative attitudes towards women would have been sifted. Nonetheless, the Vice President of the Democratic National Committee, Katie Louchheim, who addressed The Women's National Party said that women needed to "win for ourselves the acceptance of the fact that [we] are people [too]." 856 The group was reported as "dedicated to the passage of a constitutional amendment to guarantee women equal rights with men.” Women, she said, just like men, had "varying interests" and men "with a social conscience" thought like "women with a social conscience." The problem, in Louchheim's view, was "over-domesticated women in their thinking about public affairs."

Political changes were not as opaque social transitions. On 2 January 1960, the New Haven Evening Register noted that then Democratic Senator from Massachusetts, John F. Kennedy, was "set to make it [bid for the Presidency] official." 857 This was of importance for a number of reasons, one of which was the fact that he was Roman Catholic and, if elected President, would be the first President who was a member of that faith. Later that year, on 6 November 1960, Kennedy had visited Waterbury, Connecticut. Approximately 40,000 people waited until 3 A.M. on a cold winter night to hear him speak from the balcony of the Roger Smith Hotel ${ }^{858}$ Kennedy's Press Secretary, Pierre Salinger, was to later recall that this "was the greatest night of the campaign."

On January 21, 1961, Democrat John Fitzgerald Kennedy was sworn in as President of the United States. The inauguration was held in "the freezing aftermath of driving

855 New Haven Register, January 6, 1960, 1.

856 Ibid., p. 6.

857 New Haven Evening Register, January 2, 1960, 1.

858 Please see http://en.wikepedia.org/wik./Waterbury, Connecticut, accessed on February 27, 2008. 
snowstorm" that enveloped the east coast of the United States. New Haven recently re-elected Mayor Richard C. Lee declared a state of emergency as "a blizzard whipped the state, shutting schools, banks, business and industry and keeping most people indoors." ${ }^{859}$ Kennedy became the $35^{\text {th }}$ President of the United States at 12:51 P.M. ten minutes after Lyndon B. Johnson was sworn in as Vice President. The New Haven Register used the UPI story of the inaugural that reported "World Peace Top Goal of New Leader.” Kennedy's 1300 word speech addressed not only Americans, with its classic challenge to "ask not what your country can do for you, but what you can do for your country" but also to "my fellow citizens of the world" who should ask "not what America will do for you, but what together we can do for the freedom of man." As to Cuba, Kennedy said, "Let every other power know that this hemisphere intends to remain the master of its own house." As temperatures continued to plunge, John M. Dempsey, originally a native of Ireland, was sworn in as the Democratic Governor of Connecticut, a clear sign that the state had changed from its 1930s attitude toward immigrants. 860

As with the previous case, it is important to establish what socio-cultural conditions existed that may or may not have contributed to a sense of "moral panic" in the country. Although local economic indicators may not have been bright, Associated Press reporter Jack Lefler filed a report, reprinted in the Register, which noted that the nation's 1959 business activity exceeded experts' expectations. Although a steel worker strike of 116 days had taken place in 1959, the December industrial production was "near the all-time highs of the pre-strike period in steel." ${ }^{861}$ On 4 January 1961, the United States and Cuba severed diplomatic ties and the Register noted this was a "genuine misfortune." 862 But it minced no words, calling Fidel Castro a "megalomaniac" and said, "there was no other choice." It predicted "difficulties ahead" and said Guantanamo was a "problem of explosive proportions", whether the United States chose to keep the base or not.

The economic situation might not have been a problem but race relations were significantly troublesome; desegregation in America's South was finally becoming a reality. In 1954, the Warren-era Supreme Court of the United States in Brown v. Board of Education, 347 U.S. 495 (1954) (Brown I) had decided that "[s]eparate educational facilities are inherently unequal." ${ }^{863}$ In 1960, African-Americans Hamilton E. Holmes

859 New Haven Register, January 20, 1961, 1.

860 New Haven Register, January 24, 1961, 1.

861 Ibid., p. 16.

862 New Haven Register, January 4, 1961, 26.

863 Laurence H. Tribe, American Constitution Law (Mineola, New York: The Foundation Press, 1978), 1019 -1020. Brown v. Board of Education, 349 U.S. 294 (1955) (Brown II) addressed the issue of appropriate relief pursuant to Brown I. Brown I reviewed the "separate but equal" rationale found in Plessy v. Ferguson, 163 U.S. 537 (1896). There, “equal but separate accommodations for the white and colored races" met with the Court's approval; if they were unequal it had nothing to do with "anything found 
(age 19) and Miss Charlayne Alberta Hunter (age 18) were refused admittance to the University of Georgia in Athens and challenged that decision in Holmes v. Danner. On 4 January 1961, Federal District Court Judge W.A. Bootle (1902-2005) ruled that the university had discriminated against the two on the basis of race and ordered their immediate admittance. Demonstrators hung an effigy of Holms from an arch at the university and burned a "small cross" near a freshman dormitory after the ruling. Georgia's state law prohibited the use of state funds in the operation of either integrated educational institutions or those ordered to be integrated. However, it was pinned under another order to desegregate Atlanta public schools that September. ${ }^{864}$

Four days after his first order to admit Holmes and Hunter, Judge Bootle again had to issue a temporary injunction ordering the Governor of Georgia, Ernest Vandiver, and the State Auditor, R.E. Thrasher, from obeying Georgia state law and cutting off funds or withholding operating funds from the University of Georgia at Athens. On the front page of the Register, over the headline "U.S. Judge Bars Governor From Closing Georgia U.”, appeared yet another harbinger of tense days to come, "U.S. Will Continue Maneuvers Despite Protests of Castro."

In mid-January a full-page advertisement appeared in the Register, with 6 × 3 3/4 inch pictures of Presidents Eisenhower and Kennedy side-by-side under the banner "We are challenged as a people. We are summoned as a nation." ${ }^{866}$ Under the pictures the text noted that there existed "worldwide unrest" and a "precarious peace." It was an advertisement a book, Goals for Americans, which came out of the Report on National Goals, a report that advocated public involvement in the "decade of decision ahead." ${ }^{867}$ The Report set as major goals at home, among others, to "Improve educa-

in the [state] act [mandating racial segregation of railroad passengers]" and if there was any badge of inferiority it was "solely because the colored race chooses to put that construction upon it." Tribe, Constitutional Law, 1019-1020. This is another example of a type of legal "relativity" where the reality held by some is blamed by those holding another reality for "non-existent problems" the first group says it has.

864 New Haven Register, January 7, 1961, 2. Dwight D. Eisenhower appointed William Augustus Bootle to the Federal District Court in Georgia in 1954. Three days after ordering the two students to be admitted to the University, he stayed (blocked) his own order since the University had appealed it to a higher court. Until the end of his life he maintained that the stay of his own order was "business as usual." Finally, he revealed to Professor Robert A. Pratt that he did so in order to get the case before the Fifth Circuit and the Supreme Court as soon as possible. Donald L. Hollowell (1917-2004) and Constance Baker Motley (1921-2005), attorneys for the two students, then petitioned Judge Elbert P. Tuttle of the United States Court of Appeals for the Fifth Circuit, who overturned Bootle's stay. On 10 January 1961, the University took its case to Justice Hugo Black, a former Klu Klux Klan member, who turned it over to the full Court. The Court upheld Tuttle's ruling but on 11 January when Holmes and Hunter tried to attend classes, rioting broke out at the university and the university suspended them, ostensibly for their own safety. On 12 January, Judge Bootle ordered them reinstated.

865 New Haven Register, January 10, 1961, 1.

866 New Haven Register, January 19, 1961, 3.

867 Ibid. 
tion so that every child is educated to his full capacity", to "Reduce the last barriers to full respect for every individual - especially that of race" and to "Bring high quality medical care within every American's reach.” Abroad, the goals included the fight against Communism, arms stabilization and a strengthening of the United Nations as well as confining "outbreaks of violence anywhere in the world."

The "space race" was narrowed by Americans, who on 1 February, made a fourth successful launch from Cape Canaveral in which a "space chimp" named "Ham", riding inside a Mercury capsule, survived the launch of a Redstone Minuteman missile and its 420 mile journey. ${ }^{868}$

Normative political practices as regards the techniques of social movement organizations (SMO) ${ }^{869}$ were changing in major ways. On a spring day in March, the Waterbury Republican used a term in its first editorial that most Americans had little familiarity with but which, in retrospect, became a fixed political tactic of the 1960s and beyond. The Republican's editorial titled "Passive Resistance" noted how interest in the idea had "surged" in the "past two years." ${ }^{870}$ The editorial mentioned the boycott of segregated buses in Montgomery, Alabama, sit-in demonstrations at lunch counters and "pray-ins" against racial segregation. William S. Nelson, then Vice President of Howard University, was teaching a course in the philosophy of nonviolence and was especially suited to the job since he "has visited India and once knew Gandhi personally." 871 The editor of the Republican was insistent in giving credit to American transcendentalist writer, Henry David Thoreau, however

It is remarkable that in all the references to Gandhi as an example to the American Negro's passive resistance against segregation credit is never given to the prototype of the idea: Henry David Thoreau....It is an American idea, after all, and Gandhi freely acknowledged the inspiration he gained from reading Thoreau as a youth in South Africa....It is part of American heritage. ${ }^{872}$

Ascribing "passive resistance”, in light of the work and success of Gandhi, to American heritage, while technically true to a point, tends to undermine the work Gandhi did and minimizes the successes he achieved, i.e. the liberation of a nation. Thoreau's time in jail for refusal to pay a poll tax that indirectly supported slavery is not a fair comparison. The resistance of feminists aimed at protesting against their lack of civil rights in Britain is a fairer comparison, especially since some died, but it comes nowhere near to Gandhi's use of and success with the strategy.

868 New Haven Register, February 1, 1961, 1.

869 SMO is an acronym for social movement organizations. Please see Chapter 2.

870 Waterbury Republican, March 1, 1961, 6.

871 Ibid.

872 Ibid. 
In the Suburban Section of the Waterbury Republican on Sunday 22 March was a full-page advertisement by the Shell Oil Company. ${ }^{873}$ The headline read "Bulletin: Shell Research scientists reveal how they got 168.47 miles per gallon.” Using a "highly modified” 1924 2-passenger coupe that Shell "rescued from a junkyard for \$35”, Dave Berry and Fred Schuette won a marathon competition, using tires that were a yard in diameter plus other significant changes. Shell's message was that its new "mileage booster" Platformate released " $11 \%$ more energy than the finest 100-octane aviation gasoline." ${ }^{874}$ Whether or not Shell had some knowledge of international oil reserves is unknown; the point is that many of the issues seen in the Republican resurfaced a mere 30 years later, be they state vouchers for private education or the fuel efficiency of carbon-based machinery. Even the gas crisis of the 1970s in the United States would be all but forgotten by the media by the turn of the century.

Late in March, President Kennedy warned Russia that the United States and her allies would "have to consider their response" to the fact of "armed attacks by Communists rebels" in "war-scourged Laos." ${ }^{875}$ Kennedy later opened a news conference with a statement on Laos and "huge maps" charting the "progressive communist conquests of Laos since late August." Kennedy's thesis was that the fall of "the little mountain kingdom" would "endanger the security of all Southeast Asia" as well as affecting the security of United States. Kennedy hoped that that Russia would agree to a British-backed proposal for a cease-fire and start to negotiations. ${ }^{876}$

Pacifists were again on the front page of the Republican when the New England Committee for Non-Violent Action was pictured with placards passing "through Waterbury yesterday on their 300-mile route from Kittery, Maine to the U.N. building, New York.” Pictured in the lead was Richard Zink, age 20, who had boarded the nuclear submarine USS George Washington in October 1961 before being pushed into the water by "defending sailors." In the picture that accompanied the story was one of first uses of what has since become known as the "peace sign" but which the Republican reported as a "semaphore language for 'nuclear disarmament'." 877 The marchers gave lectures and movies at the local YMCA before moving on to New York. The leader had been Robert Swan who had spent two years in jail during World War II "for his pacifist views." Swan had become ill and his wife had to replace him as leader of the group and she had herself spent six months in jail in Omaha, Nebraska for illegally entering a missile base there. The Republican described the marchers as

873 Waterbury Republican-American, March 22, 1961, Suburban Section, 2.

874 Ibid.

875 Waterbury Republican, March 24, 1961, 1. Flush Left.

876 Ibid.

877 Gerald Holtom designed the "peace sign" in 1958 for the anti-nuclear march from London to Aldermason. It is based on the semaphore signals for "N"(nuclear) and "D" (Disarmament). I am grateful to Prof. Ann Sætnan for this information. 
A curious blend of the old and the young, the beaten and the defiant, bearded and the clean-shaven, the zealous self-admitted anarchist and the college boy just out to get away from classes. ${ }^{878}$

In this report there is a bit of bemusement about the entire episode, the type of episode that would eventually become common fare for television viewers across the United States during the late 1960s and early 1970s. But one should note the reference to anarchy, a contributing factor to the "moral panic" that we have already seen in the previous case.

A major reason that this would become a status quo practice at this time was the earlier Civil Rights Movement; this social movement organization produced changes that women's groups would then take as models for changing social norms for women. For example, we read that after one group of black and white "Freedom Riders" had been arrested upon their arrival by bus in the Mississippi capital of Jackson, Attorney General Robert F. Kennedy issued a plea for them to slow down the pace of desegregation actions saying, "A mob asks no questions." ${ }^{879}$ Twenty-seven people from two buses were eventually arrested and put in jail for "breach of peace, disobeying an officer and attempting to incite a riot." Jackson city police ringed the bus station, some with dogs, and arrested the group when they entered a "white only" waiting room. They were asked to leave but refused and were "accommodated" by Jackson Chief of Police, W.D. Reyfield. A \$500 bail was set for each charge, which none managed to obtain until the N.A.A.C.P. (National Association for the Advancement of Colored People) posted the $\$ 1500$ bail for each person. The incitement to riot charge was dropped and the cases were to come before Jackson Municipal Court the following day. About 100 national guardsmen with rifles maintained a vigil at the Meridian bus station in anticipation of more Freedom Riders. Paul Dietrich, a 29 year old white man from Washington D.C. and the Rev. James M. Lawson, a "Negro minister from Nashville" were arrested along with the group.

This was also time of an unsettling "moral panic" in the United States. Schemas and structures were clearly changing and the outcome was, as yet, unknown. If anything, we saw the same set of Pescosolido factors present in Case One in Indiana (1907). Social life was again being transformed, this time from the "modern" to the "after-modern" (postmodern) just as Indiana had previously experienced the beginning of a change from "pre-modern" to "modern" societal structures and articulations. In this new social arrangement, membership in any given social circle could be both chosen and inherited, i.e. chosen, for example, by one's work but inherited as in the case of membership in a family. The "moral personality" of the individual

878 Waterbury Republican, Sunday, March 26, 1961, 1. Flush Right.

879 Waterbury Republican, May 25, 1961, 1. Flush left. 
was "circumscribed in a new way." individual and religion will lose its former dominance.

\subsection{Denouement: The Equal Rights Amendment}

As we shall see in the Norwegian half of this Case, an Equal Rights Amendment was also considered during this period of social change. In the United States, the politics of birth control issues essentially culminated with women winning the right to have an abortion through "judge-made law" in 1973 in the Supreme Court case Roe v. Wade (1973) 410 U.S. 113, 93 S.Ct. 705, 35 L.Ed. 147. But, at the same time, women failed to win any legislatively enacted law directly related to the equality of the sexes. The Equal Rights Amendment (ERA) had been revived during the 1960s. Originally, Alice Paul (1895-1977) had first been proposed it in 1923 at the $75^{\text {th }}$ anniversary of the 1848 Seneca Falls Women's Rights Convention. Then, it was called the "Lucretia Mott Amendment”, after Quaker abolitionist and suffragette Lucretia Mott, and it read; "Men and women shall have equal rights throughout the United States and every place subject to its jurisdiction."

The Congress of the United States passed the ERA on 22 March 1972; however, as a matter of procedure, because it was passed as a proposed amendment to the Constitution, it also had to be subsequently passed by two-thirds of the states. This meant that 38 of 50 states had to pass it within their own legislatures. The amendment had a seven-year deadline for passage of the proposed clause. Within a year of its proposal, the amendment was passed in 22 states. In 1973, 8 states ratified the amendment, in 1974, 3 states, and in 1975, 1 state. Opposition came from states' rights quarters, business interests such as the insurance industry, and right-wing fundamentalist religious organizations.

In 1977, Indiana ratified the amendment, the last to do so to date. The sevenyear deadline soon became a serious impediment and in 1979, only after a march of 100,000 citizens in Washington D.C., did Congress extend the deadline for passage until 20 June 1982. Despite concerted effort by proponents, no other states ratified the amendment. In 1980, the Republican Party removed it from its platform as Ronald Reagan was elected President.

On 14 July 1982 the Equal Rights Amendment was again proposed in Congress. In the 107th Congress (2001-2002) Senator E. Kennedy of Massachusetts re-introduced it as S.J. Res 10 and Representative Carolyn Maloney of New Jersey as H.J. Res 40, both of which contained no deadline for ratification as the previous amendment had, and it has been re-introduced during every Congress since then.

880 Ibid., 56. 
For the time being, in the United States at the level of the Supreme Court, the rulings in Griswold and Roe seem to have been the culminating point for women's rights, reproductive or otherwise. While it is true that various states have undertaken to protect women workers in various ways, in terms of reproduction and equality, these cases remain the limit of legal self-determination over reproduction by women. What is also important, as we shall see in the next chapter, is that - by comparison Norway's enactment by its Parliament of both an abortion law and an ERA in 1978 has produced far better results in terms of societal acceptance and practice.

\subsection{Jasanoff Fields, Changes in Scientific and Institutional Discourses}

How had the Jasanoff fields worked to introduce new paradigms in American society

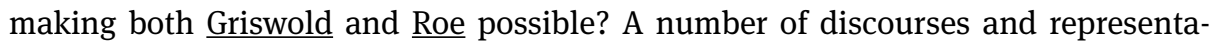
tions, as well as institutions and identities, had changed between the 1930s and the 1960s. One such discourses was of "women as workers.” For example, in July 1939 the Democrat ran an article on the Massachusetts Women's Club President, Florence Birmingham. Birmingham had challenged Eleanor Roosevelt to a public debate on the proposition "Should wives be permitted to hold jobs outside the home?"881 Eleanor Roosevelt declined the offer but Edwina Austin Avery, a suffragette and member of the National Association of Women Lawyers, took up the "cudgel on behalf of the Working Wife." 882 Both were afforded space in the Democrat along with John T. Flynn who was to "view the question through the unprejudiced eyes of an economist." 883 What was ultimately at issue wasthe current national legislation outlawing married women the right to work. By 1939, 30 legislatures had seen such attempts.

But in the early 1960s, other ideas of what was the proper place and role for women were in circulation. Feminist Betty Freidan was not the first woman to question her role as a wife and a mother in American society. Her analysis of these roles, however, did have an energizing effect within the women's movement at this time. One important thing to note here is that parts of a typewritten manuscript as well as reprints of some of her lectures can be found in Justice Douglas' files in the Manuscript Room of the Library of Congress. ${ }^{884}$ Despite theory to the contrary, what Douglas read and had

881 Waterbury Evening Democrat, July 14, 1939, 22.

$\mathbf{8 8 2}$ Ibid.

883 Ibid.

884 In the summer of 2006, I reviewed the files of Justice William O. Douglas at the Manuscript Room at the Library of Congress in Washington, D.C. Several copies of corrected and re-corrected page copies of the Griswold text could be found there, as well as some memorandums about Griswold. More interesting, however, were several items from or about Betty O. Freidan. Included in those files were a paper copy of remarks she given to the Cornell University Intersession on Women, Ithaca, New York 
experienced did affect his thinking and his willingness to "find" or "discover" the law of privacy in the penumbra ${ }^{885}$ - that vague, shadowy are around the Constitution.

Discourses on the nature of what it meant to be a "real" woman had also changed dramatically in the intervening years between Case One and this Case. The "American Mother of 1939" was Otelia Compton, highlighted in the Waterbury Democrat. Mother of four, including Nobel winner in Physics (1927), Arthur H. Compton, she credited her parenting success to prayer. She worked her way through college and earned her degree after ten years; she then married her teacher, Elias Compton, who eventually became President of Wooster College. She was chosen Mother of 1939 by the Golden Rule Foundation as "representative of the best there is in womanhood", the "[u]narticulated voice of millions of mothers throughout the nation." 886 Rev. Dr. John C. Walker, pastor of the Second Congregational Church, echoed this sentiment in his sermon of 14 May 1939, saying that motherhood was the "best...noblest and most inspiring of all earthly vocations...." 887 The Christian mother was not only the strength of the church but also of the state.

In 1961, the New Haven Register ran an interview with social psychologist, Mack Hanan. He urged women whom he saw as "the sex which still retains rights to nonconformity" to prepare the nation for change by preparing their children "to dare." The review tagged Hanan's book The Pacifiers as an "angry new book about America's soft-soap self-image." Saying that women were still allowed to different, "emotional, intuitive, even frivolous", they should encourage their child to be independent thinkers. He suggested mothers encourage children to get pen pals from different countries, visit different Churches on Sunday or join a dramatics club. Hanan was quoted as saying that the country was "a society in detour." America was "neither in favor of very much nor against very much, we are mostly just going through life

January 22/25, 1969, entitled "Tokenism and the Pseudo-Radical Cop-out: Ideological Traps for New Feminists to Avoid.” I also found an unidentified magazine text of a two-part article, part one entitled "Television and the Feminine Mystique" and part two entitled "The Monsters in the Kitchen" and several pages of corrected typewritten text. Although this text could have been part of Friedan's manuscript for The Feminine Mystique, published in 1963, it has more the sound of another book by Friedan, “The Second Stage, It Changed My Life: Writings on the Women's Movement.” There is also a business card from Charlotte L. Mayerson of Random House in Douglas' files and it is possible that Mayerson sent Friedan's materials to Douglas.

885 The use of the word "penumbra" is taken from the Griswold decision itself in which Douglas wrote: "The foregoing cases suggest that specific guarantees in the Bill of Rights have penumbras, formed by emanation from those guarantees that help give them life and substance.” The dictionary definition of "penumbra" is that it is "a partial outer shadow that is lighter than the darker inner shadow (umbra), for example, the area between complete darkness and complete light in an eclipse.

886 Waterbury Democrat, May 15, 1939, 14.

887 Ibid. 
together, conditioned to accepting the symbol for the substance, the bypass for the thoroughfare." 888

By 1965, medical technology also offered women new choices regarding if and when to become pregnant. Medical institutions in the United States represented to the American public that the oral contraceptive was safe and a prudent way to control the number of children a husband and wife decided to have in their family. In August, 1960 the Food and Drug Administration in the United States had approved sale of the birth control pill to the public after a submission by G.D. Searle \& Co. ${ }^{889}$ Trade-named "Enovid", credit was given to two men for its development, Dr. Gregory Pincus, Ph.D. (1903-1967) of the Worcester Foundation for Experimental Biology at Harvard and Dr. John Rock (1890-1984) of Harvard Medical School. Approval was given for women to use the pill for up to two years, although Dr. Alan Guttmacher, of Planned Parenthood of America's Medical Committee was quoted as saying that no adverse side effects had been noted with use up to 44 months. ${ }^{890}$

Ironically, Dr. Rock, who had been born in Marlborough Massachusetts, had been raised a committed Roman Catholic. As a young man of 14, his parish priest told him to "Always stick to your conscience. Never let anyone keep it for you. And I mean anyone else." ${ }^{891}$ After taking a job after his high school graduation where he was exposed to the living conditions of banana plantation workers in Guatemala, Rock decided to attend Harvard University in 1912. In 1915 he went on to Harvard Medical School and began working as an obstetrician. In 1922, he was appointed an Assistant Professor of Obstetrics at Harvard Medical School where he was able to conduct research on human fertility. In 1939, he opened the first "rhythm" clinic at the Boston Free Hospital for Women. His intention was to assist infertile women so that they could identify the best time for conception.

Dr. Gregory Pincus, who would work with Dr. Rock, had been appointed Assistant Professor at the same university in 1931, where he conducted research on ways to prevent conception by working on the effect of progesterone on rabbits. It was Margaret Sanger who introduced Pincus to Katharine McCormick, heiress to the McCormick threshing machine fortune. McCormick quickly gave Pincus $\$ 40,000$ to support his work. Pincus, however, was not a medical doctor and this restricted the type of research he could conduct. Pincus approached Rock, who was then nearing retire-

888 New Haven Register, January 3, 1961, 15. Or, see also, Mack Hanan, The Pacifier: The Six Symbols We Live By (Boston: Brown, Little, 1960).

889 Marriage and Family Living, August 1960, 242.

890 Ibid.

891 Malcolm Gladwell, “John Rock’s Error: What the co-inventor of the pill didn't know about menstruation can endanger women's health” in The New Yorker, Department of Human Resources, March 13, 2000, 52. Also see, Loretta McLaughlin, The Pill, John Rock and the Church: The Biography of a Revolution (New York: Little, Brown and Company, 1982) and Lara V. Marks, Sexual Chemistry: A History of the contraceptive Pill (New Haven: Yale University Press, 2001). 
ment. Although Rock was socially conservative and still a faithful member of the Roman Catholic Church, he nonetheless believed in population control. With McCormick's money, Pincus and Rock started drug trials on 50 women which they labeled a "fertility study" to avoid any problems. By 1955, they realized that the science was available for what we now call the birth control pill.

Six years earlier, in 1949, Rock had collaborated with David Loth and written a book entitled Voluntary Parenthood. ${ }^{892}$ Christopher Tietze, a reviewer forThe Quarterly Review of Biology, pronounced the book "verbose" and with too much emphasis on technical detail for the average reader. One chapter was entirely devoted to the Catholic point of view that, according to Tietze, was "fairly represented by the Rev. Francis J. Carroll of the Catholic University of America.” Of this chapter, Tietze wrote, the "implications of this point of view are only hinted at, and are not discussed."893

Eventually Rock, the father of five children, realized that the Vatican needed to be convinced and he and population control supporters both emphasized the "natural" use of hormones to mimic a woman's monthly fertility cycle. Rock wrote a book outlining his work entitled The Time has Come: A Catholic Doctor's Proposals to End the Battle over Birth Control. The book was published in 1963, two years before Griswold was decided. This time, Carl G. Hartman reviewed Rock's book for The Quarterly Review of Biology. ${ }^{894}$ Hartman wrote that Rock worried equally over both his "fecund and his infertile” patients. Rock's own Bishop was Richard James (Cardinal) Cushing (1895-1970). From 1944 to 1970, Cushing served as auxiliary Bishop of Boston and was elevated to the College of Cardinals in 1958 by then Pope John XXIII (r. 19581963). Cushing was also a "close friend" of the Kennedy family and had married John Kennedy and Jacqueline Bouvier in 1953. In 1963 Cushing was Archbishop of Boston and was quoted as saying about Rock's book that:

In this book there is much that is good... [The author] has clearly demonstrated that the Church is not opposed to birth control as such, but to the artificial means to birth control. ${ }^{895}$

Cushing's statement is an elusive one, especially in view of the current position of the Roman Catholic Church on the subject. It can be read as demonstrating that even the Church, in addition to society at large, was in the process of developing an opinion about birth control. But, it can also be read as indicating that Cushing was of the

892 John Rock and David Loth, Voluntary Parenthood (New York: Random House, 1949).

893 Christopher Tietze, "Voluntary Parenthood" in The Quarterly Review of Biology, 25 (1950): 122. 894 Carl G. Hartman, "The Time Has Come” in The Quarterly Review of Biology, 38 (1963): 286-87.

895 Hartman, Time Has Come, 287. Please see, http://www.en.wikipedia.org/w/index.php?title= Richard_Cushing\&printable=yes, accessed on February 28, 2008. This article also makes the following observation, without footnoting any source that "Cushing was essentially tasked with making the Roman Catholic acceptable to the general American population in preparation for then Senator John R. Kennedy's run for the White House." 
opinion that the use of the body's natural hormones was a "natural" means of birth control. ${ }^{896}$

Opinions by Rock and Cushing aside, Hartman wrote in his book review "Rock's theology is not up to his medicine." The Church had actually already decided that Rock's method was unnatural. With no little prescience, Hartman wrote that the Church's negative reaction to the use of progesterone:

is but one illustration of decisions which the Church will have to make in the future, decisions perhaps more difficult and doubtless more fateful for humanity than the rejection in the days of Copernicus of the geocentric theory of the universe. ${ }^{897}$

Hartman took time to address the issue of over-population and contrasted President Eisenhower's “cold, laissez faire, negativistic attitude" of encouraging population control to the attitude of the new President, John F. Kennedy, his State Department and his new Secretary of Health, Education and Welfare, Anthony J. Celebrezze. Both Kennedy and Celebrezze, despite being Roman Catholics, were much warmer toward the idea of population control.

Rock did include in The Time Has Come a "vivid picture of the battlefield" between Catholics and Protestants on the issue of birth control. Rock held out hope and included in his book an entire chapter devoted to "arguments for conciliation and peaceful coexistence." 898

But attitudes within the Roman Catholic Church routinely change at glacial speed. Telling the Vatican "the time has come" was of no moment to those who walked the halls there. On 25 July 1968, the encyclical Humane Vitae ${ }^{899}$ was issued by then Pope Paul IV (1897-1978) (r. 1963-1978). This document, relying on the 7 dissenting votes of the 72-member Committee that studied the issue of birth control, refused to allow the use of synthetic hormones to regulate births. The encyclical merely noted, without giving the number of votes in the Committee, that there had not been "complete agreement" about "the moral norms proposed." 900 Humane Vitae analyzed numerous ideas including that of "responsible parenthood" that, it said, "concerns the objective moral order which was established by God, and of which a right conscience is the true interpreter." ${ }^{\text {901 }}$ Despite this fig-leaf bow to the supremacy of conscience, thereby

\section{Ibid.}

897 Ibid.

898 John Rock M.D., The Time Has Come: A Catholic Doctor's Proposals to End the Battle over Birth Control (New York: Alfred A. Knopf, 1963). See Chapter 11.

899 "On Human Life" and subtitled "On the Regulation of Birth."

900 Paul VI, "Special Studies" in Humanae Vitae, 2 at http://www.vatican.va/holy_father/paul_ vi.encyclicals/documents/hf_p-vi_enc_25071, accessed on November 17, 2006.

901 Ibid., 4. 
avoiding its own problems with Vatican II and stare decisis, the document ultimately said that:

We are obliged once more to declare that the direct interruption of the generative process already begun and, above all, all direct abortion, even for therapeutic reasons, are to be absolutely excluded as lawful means of regulating the number of children.... Equally to be condemned...is direct sterilization.... Similarly excluded is any action which either before, at the moment of, or after sexual intercourse, is specifically intended to prevent pro-creation - whether as an end or as a means. ${ }^{902}$

None other than the Bishop of Kraków, Karol Wojtyla, later Pope John Paul II, contributed a major portion of the wording of Humanae Vitae. Wojtyla later supported the encyclical with his own 1993 encyclical, Veritatas Splendor. ${ }^{903}$

In the end, timing may have been everything for the issue of birth control and the institution of the Roman Catholic Church. Later research, especially that done by medical statistician Malcolm Pike between 1980 and 1981 and oncologists Darcy Spicer and John Daniels, would have allowed Rock to argue that, in essence, the pill was an anti-cancer drug, saving the lives of women from breast cancer. ${ }^{904}$ This is the argument of Malcolm Gladwell makes when he writes that this entire scenario was neither the fault of Rock nor of the Church. As Gladwell writes:

It was the fault of the haphazard nature of science, which all too often produces progress in advance of understanding. If the order of events in the discovery of what was natural had been reversed, [Rock's]...world and our world, too, would have been a different place. ${ }^{905}$

Perhaps this is too generous of an interpretation of the facts by Gladwell in light of the overwhelming number of members who were on the Vatican commission on birth control had voted to approve use of it. In 1968, an aging Dr. Rock finally followed his conscience as his parish priest had once encouraged him to do and stopped attending the Church to which he had belonged his entire life.

The institutional Roman Catholic Church was also weakened throughout the 1960s. This "secularization" of Catholics living in the United States did not start with John Kennedy's election. Second-generation American Catholics had been at least

902 Ibid., 5. It is interesting that the encyclical begins with abortion, moves to sterilization and then finally - to birth control. One would think that the reverse, if anything, would have been the logical construction. This begs the question that is this was written as a moral "shot-gun" approach to all matters of sexual intercourse. Offended in the extreme by abortion, that approach then "rolled down a hill" to hit birth control at a bottom wall.

903 "The Splendor of Truth", an encyclical issued on August 6, 1993.

904 Malcolm Gladwell, “John Rock’s Error: What the co-inventor of the pill didn’t know about menstruation can endanger women's health” in The New Yorker, March 13, 2000, 63.

905 Ibid. 
partially assimilated, and were "wealthier, better educated and [more] geographically diversified" than their immigrant mothers and grandmothers. ${ }^{906}$ Between 1940 and 1960, the Catholic population of the U.S. had doubled. ${ }^{907}$ Despite the fact that the pre-Vatican II Church still retained a tight hold on its flock, the GI bill had made it possible for more Catholics, veterans of World War II, to get a higher education. This post-war Catholic culture had no doubt what its answer would be to whether a Catholic could be a good citizen. In 1956, William J. Brennan had been nominated to the Supreme Court and, in a statement foreshadowing Kennedy's own statement said "What shall control me is the oath that I took to support the Constitution and laws of the United States and so act upon the cases that come before me for decision. [T] hat is the oath and that alone which governs [my actions]."908

The Roman Catholic Church may have assumed, based on earlier religious schemas that all its followers were in accord with Vatican pronouncements on sex, sexuality and birth control. But this was an untenable belief. Already in 1936, Fortune Magazine conducted a poll of the adult population and asked "Do you believe in the teaching and practice of birth control?" 909 A total of $66 \%$ of all those who were polled answered "yes" and a total of $42.8 \%$ of Catholic women who were polled answered "yes." Two years later, in 1938, a total of $79 \%$ women who answered the poll said "yes" and $51 \%$ of the Catholic women who answered said "yes." 910 By 1943, the percentage of Catholic women with a grammar school education who answered "yes" had risen to $70.2 \%$ and of those who were college graduates, the number was $92.6 \% .{ }^{911}$ Clearly, had the hierarchy been listening to its educated female membership, other assumptions about institutional Church strength might have been made.

While social and legal representations about the essential character and proper domain for the human body are at the core in this work, another interesting representation that emerges from in Case Two is the change in representation about what was the "public" realm and what was the "private" realm in American society. Progressive reformers had had no problem intruding into the reproductive lives of criminals, immigrants, ethnic and racial groups and women at the beginning of the century. These groups were not in the ascendancy in terms of political and social power and, as the "weak we", were acceptable targets of public policy, informed by a science that was often wedded to ideology. In addition, limitation of the offspring of those who were considered "degenerate", who did and would no-doubt continue to cost the state enormous amounts of money was also an acceptable, even noble, goal. This was

\footnotetext{
906 Ibid., 77.

907 Ibid., 76.

908 Ibid.

909 Harriet F. Pilpel and Theodora S. Zavin, "Birth Control” in Marriage Counseling Section of Marriage and Family Living, May, 1952, 119.
}

910 Ibid.

911 Ibid., 120. 
so, in part, because the implicit assumption was that somehow the "germplasm" of those who were citizens belonged to the nation and not the individual.

As a consequence, in terms of the body of the "other", it would become "private" vis-à-vis the state during the intervening years between Case One and Case Two. Finding that bit of privacy took form within the shade of the "penumbra" of the American Constitution. ${ }^{912}$ In short, law came to reflect the normative values of the "strong we" in the late 1960s and early 1970s. But to do this, the issue of judicialized reproductive somatechnics was placed back into the private sphere, away from any contextualization. In this respect, the outcome may have been positive and what generations of birth control supporters may have wanted, but the foundations were nowhere as near as solid as in Norway, as I will demonstrate below.

In the 1960s, after decades of organizing and twenty-five or more failed attempts in the Connecticut legislature to bypass its equivalent of the Comstock law, women and men were beginning to frame their personal reproductive health as a private matter; the body had been taken out of the public arena of the Indiana state legislature and put back into the private arena under the rhetoric of "choice."913 This was also the outcome in Norway, albeit with a different rhetorical basis, as we shall see in Chapter 6.

912 This is no doubt incomprehensible to originalists, such as Antonio Scalia of today's Supreme Court. Originalists interpret facts in light of what words meant at the time of the writing of the Constitution. But it goes without saying that no founding father had ever seen a packet of birth control pills. The founding fathers had probably never considered a human sterilization procedure either, but this had not provided any problems for the Buck court.

913 Please see, Rohan Hardcastle, Law and the Human Body: Property Rights, Ownership and Control (Oxford and Portland: Hart Publishing Company, 2007) for an update on the issue of ownership detached parts of a living and/or dead body such as tissue, DNA and cell lines. The ownership of one's own living body was thought as laid to rest with the issue of slavery. 